Prepared in cooperation with the Albuquerque Bernalillo County Water Utility Authority

Water-Level Data for the Albuquerque Basin and Adjacent Areas, Central New Mexico, Period of Record Through September 30, 2010

Data Series 623 



\section{Water-Level Data for the Albuquerque Basin and Adjacent Areas, Central New Mexico, Period of Record Through September 30, 2010}

By Joseph E. Beman

Prepared in cooperation with the

Albuquerque Bernalillo County Water Utility Authority

Data Series 623 


\section{U.S. Department of the Interior \\ KEN SALAZAR, Secretary \\ U.S. Geological Survey \\ Marcia K. McNutt, Director}

U.S. Geological Survey, Reston, Virginia: 2011

This and other USGS information products are available at http://store.usgs.gov/

U.S. Geological Survey

Box 25286, Denver Federal Center

Denver, C0 80225

To learn about the USGS and its information products visit http://www.usgs.gov/ 1-888-ASK-USGS

Any use of trade, product, or firm names is for descriptive purposes only and does not imply endorsement by the U.S. Government.

Although this report is in the public domain, permission must be secured from the individual copyright owners to reproduce any copyrighted materials contained within this report.Suggested citation:

Suggested citation:

Beman, J.E., 2011, Water-level data for the Albuquerque Basin and adjacent areas, central New Mexico, period of record through September 30, 2010: U.S. Geological Survey Data Series 623, 28 p. 


\section{Contents}

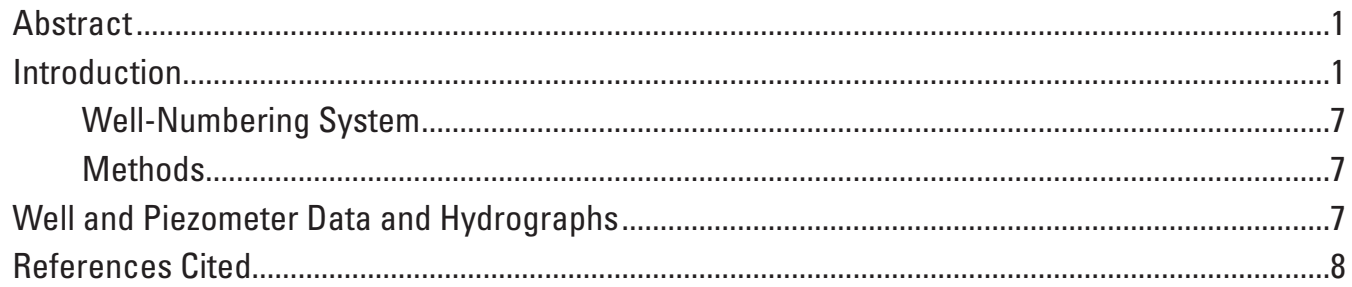

\section{Figures}

1-2. Maps showing:

1. Location of study area and selected monitoring wells and piezometers in and near the Albuquerque Basin ..........................................................................

2. Location of selected monitoring wells and piezometers within the

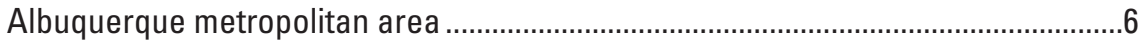

3. System for numbering wells and piezometers in New Mexico................................................

4. Graphs showing water-level data for selected wells and piezometers in the Albuquerque Basin . .10

\section{Table}

1. Data from selected wells and piezometers for the Albuquerque Basin, New Mexico

\section{Conversion Factors}

\begin{tabular}{|c|c|c|}
\hline Multiply & By & To obtain \\
\hline \multicolumn{3}{|c|}{ Length } \\
\hline foot (ft) & 0.3048 & meter $(\mathrm{m})$ \\
\hline mile (mi) & 1.609 & kilometer (km) \\
\hline \multicolumn{3}{|c|}{ Area } \\
\hline acre & 4,047 & square meter $\left(\mathrm{m}^{2}\right)$ \\
\hline
\end{tabular}

Vertical coordinate information is referenced to the National Geodetic Vertical Datum of 1929 (NGVD 29). 



\title{
Water-Level Data for the Albuquerque Basin and Adjacent Areas, Central New Mexico, Period of Record Through September 30, 2010
}

\author{
By Joseph E. Beman
}

\section{Abstract}

The Albuquerque Basin, located in central New Mexico, is about 100 miles long and 25-40 miles wide. The basin is defined as the extent of consolidated and unconsolidated deposits of Tertiary and Quaternary age that encompasses the structural Rio Grande Rift within the basin. Drinkingwater supplies throughout the basin were obtained solely from groundwater resources until December 2008, when surface water from the Rio Grande began being treated and integrated into the system. An increase of about 20 percent in the basin human population from 1990 to 2000 and about a 22 percent increase from 2000 to 2010 also resulted in an increased demand for water. A network of wells was established by the U.S. Geological Survey in cooperation with the City of Albuquerque to monitor changes in groundwater levels throughout the basin from April 1982 through September 1983. This network consisted of 6 wells with analog-to-digital recorders and 27 wells where water levels were measured monthly in 1983. Currently (2010), the network consists of 124 wells and piezometers (a piezometer is a small-diameter subwell usually nested within a larger well). To better help the Albuquerque Bernalillo County Water Utility Authority manage water use, this report presents waterlevel data collected by U.S. Geological Survey personnel at those 124 sites through water year 2010 .

\section{Introduction}

The Albuquerque Basin, located in central New Mexico, is about 100 miles long and 25-40 miles wide (fig. 1). The basin is defined as the extent of consolidated and unconsolidated deposits of Tertiary and Quaternary age that encompasses the structural Rio Grande Rift within the basin (Thorn and others, 1993). The study area extends from near Cochiti Lake south to San Acacia and from Tijeras Canyon west to near the intersection of Interstate 40 and the Bernalillo/ Cibola County line. The southward-flowing Rio Grande, the only perennial stream that extends through the length of the basin, approximately bisects the basin.

In 2000, the human population of the basin was about 690,000 (Bartolino and Cole, 2002). According to 2010 U.S. Census Bureau data, the 2010 population is about 840,000 (U.S. Census Bureau, 2011a; calculated as sum of population for census tract centers within basin). The majority of the population is concentrated within the city limits of Albuquerque, which had a population of 448,600 in 2000 (U.S. Census Bureau, 2001) and 505,900 in 2006 (U.S. Census Bureau, 2011b). The basin population increased about 20 percent from 1990 to 2000 (Bartolino and Cole, 2002; Thorn and others, 1993) and about 22 percent from 2000 to 2010 (U.S. Census Bureau, 2011a). The demand for groundwater also has increased because drinking-water supplies throughout the Albuquerque Basin were obtained solely from groundwater resources prior to 2008. Starting in December 2008, water drawn from the Rio Grande has been treated and integrated into the City of Albuquerque and Bernalillo County water supplies.

A network of wells was established by the U.S. Geological Survey (USGS) in cooperation with the City of Albuquerque to monitor changes in groundwater levels throughout the Albuquerque Basin from April 1982 through September 1983. This network consisted of 6 wells with analog-to-digital recorders and 27 wells where water levels were measured monthly. Currently (2010), the network consists of 124 wells and piezometers - 70 equipped with continuous recording data loggers and 54 that are measured with a steel or electric tape semiannually or quarterly.

To better help the Albuquerque Bernalillo County Water Utility Authority (ABCWUA) manage water use, the USGS, in cooperation with the ABCWUA, currently (2010) measures and reports water levels from 124 wells and piezometers (table 1). Water-level data collected for the Albuquerque Basin and adjacent areas for the period of record through September 30, 2010, are presented in this report. Monitoring-well locations within the basin and adjacent areas are shown in figure 1; locations within the Albuquerque metropolitan area are shown in figure 2. 


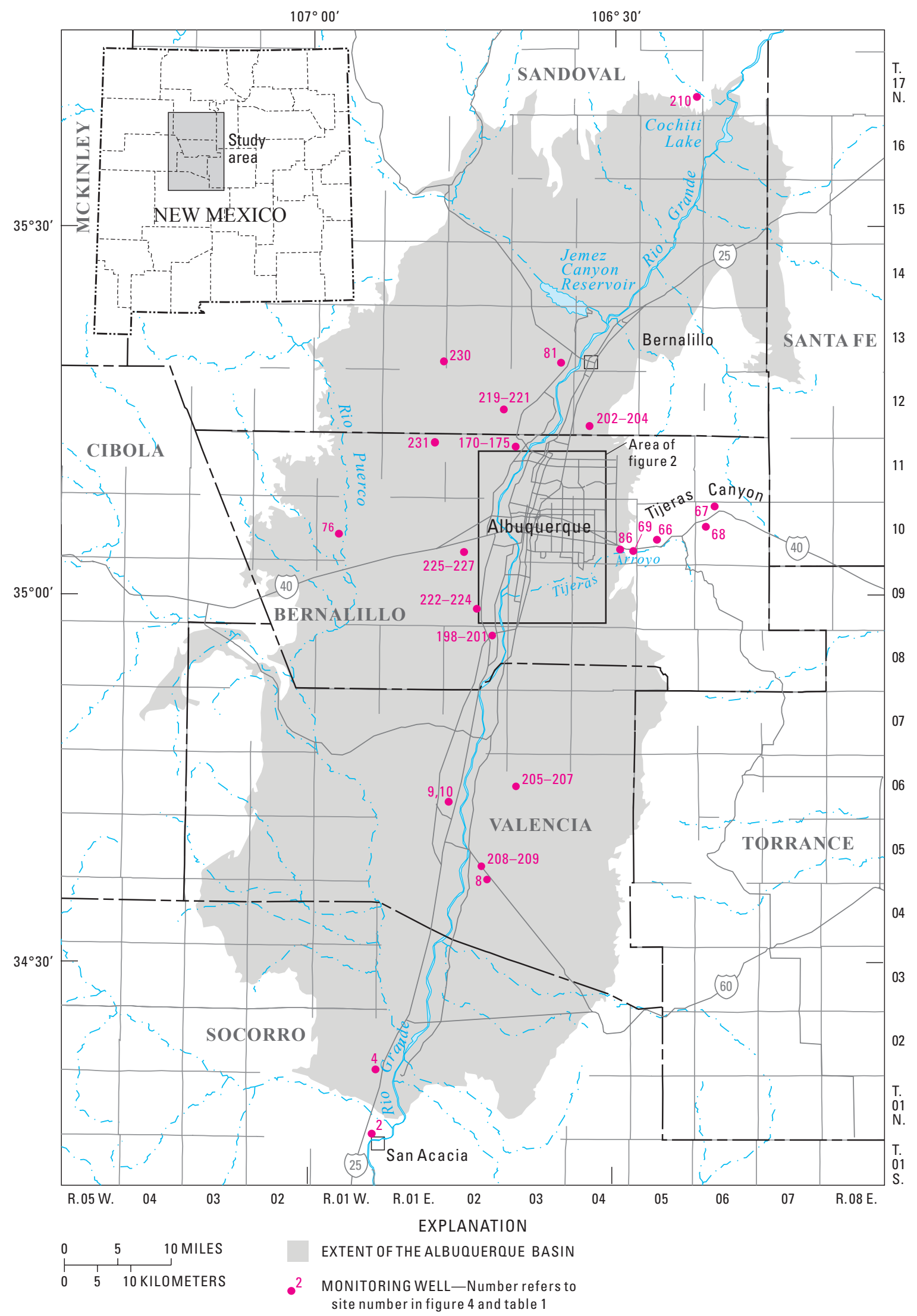

Figure 1. Location of study area and selected monitoring wells and piezometers in and near the Albuquerque Basin. 
Table 1. Data from selected wells and piezometers for the Albuquerque Basin, New Mexico.

[--, no data or not applicable. Discontinuity in numbering sequence is due to wells omitted from this report because of lack of recent data collection. Data from discontinued wells can be seen in previous issues of this report]

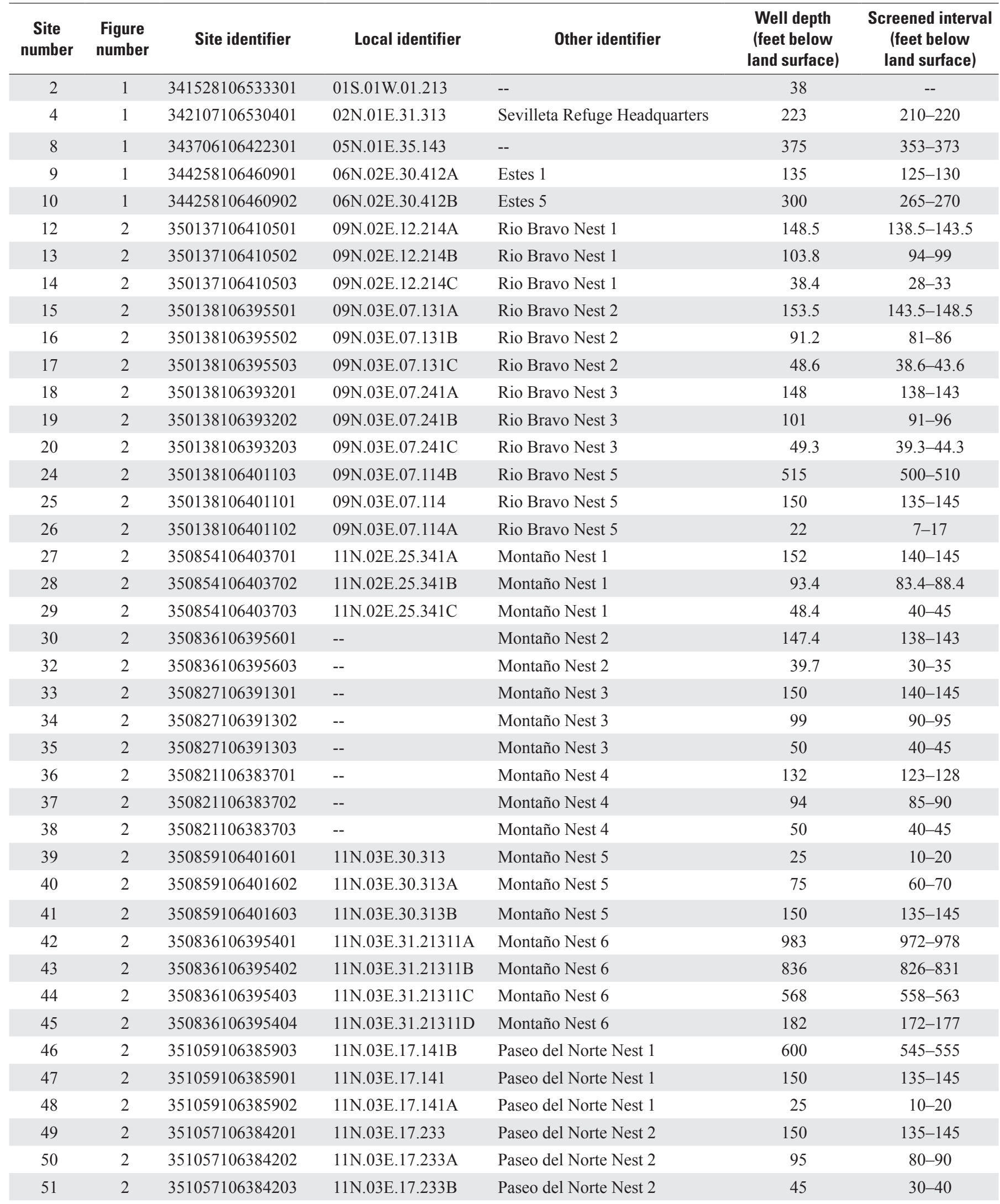


Table 1. Data from selected wells and piezometers for the Albuquerque Basin, New Mexico. - Continued

[--, no data or not applicable. Discontinuity in numbering sequence is due to wells omitted from this report because of lack of recent data collection. Data from discontinued wells can be seen in previous issues of this report]

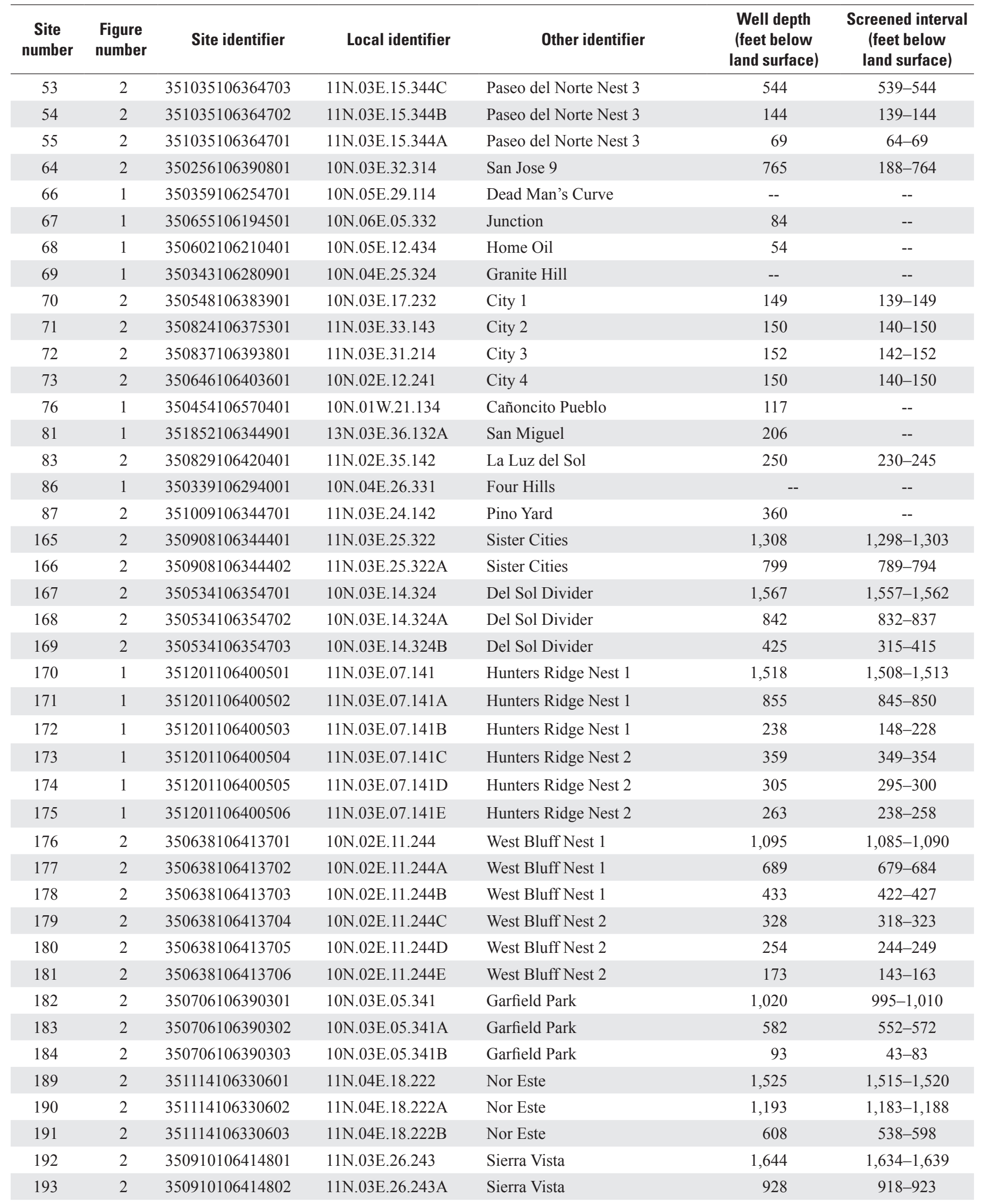


Table 1. Data from selected wells and piezometers for the Albuquerque Basin, New Mexico._Continued

[--, no data or not applicable. Discontinuity in numbering sequence is due to wells omitted from this report because of lack of recent data collection. Data from discontinued wells can be seen in previous issues of this report]

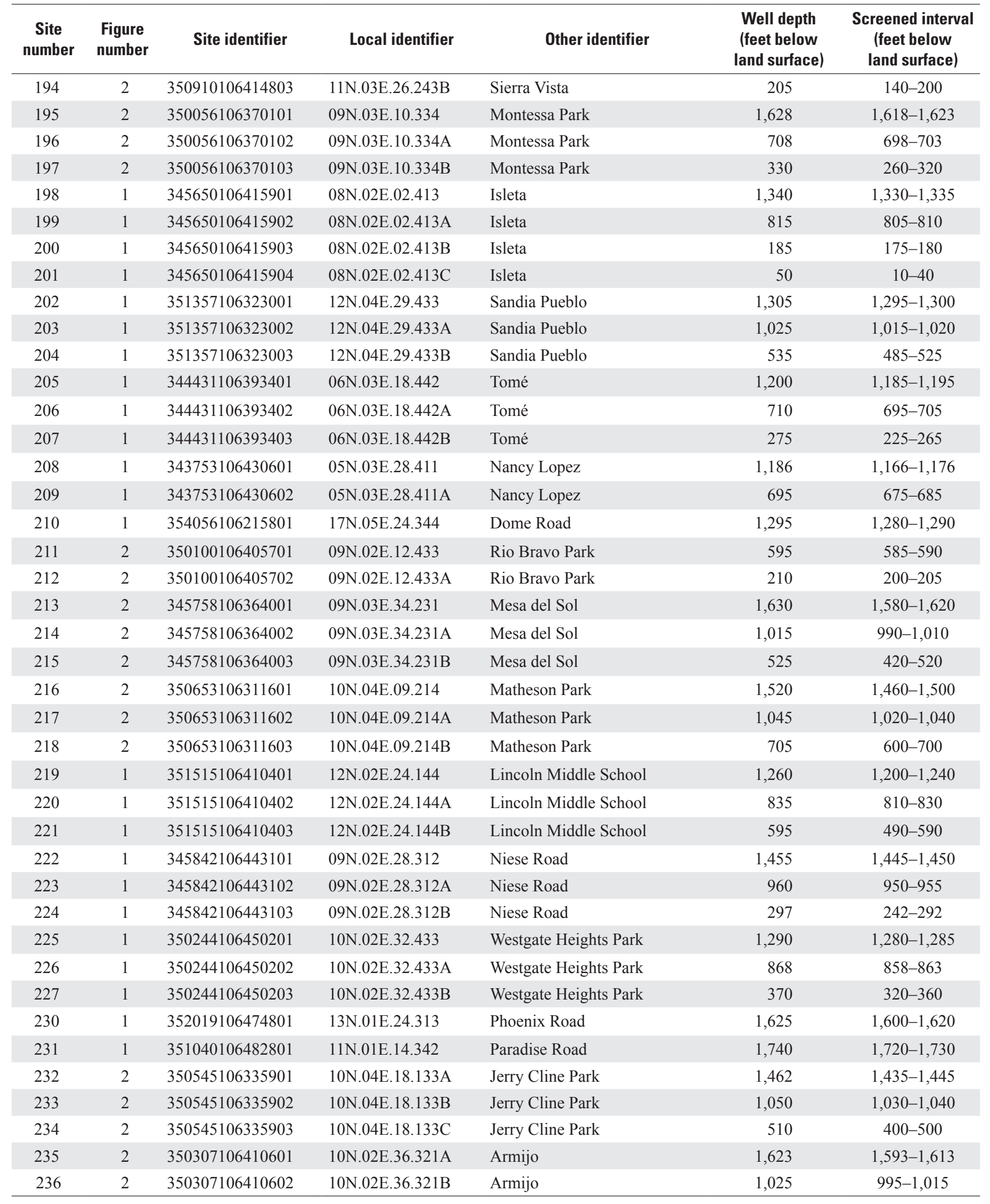




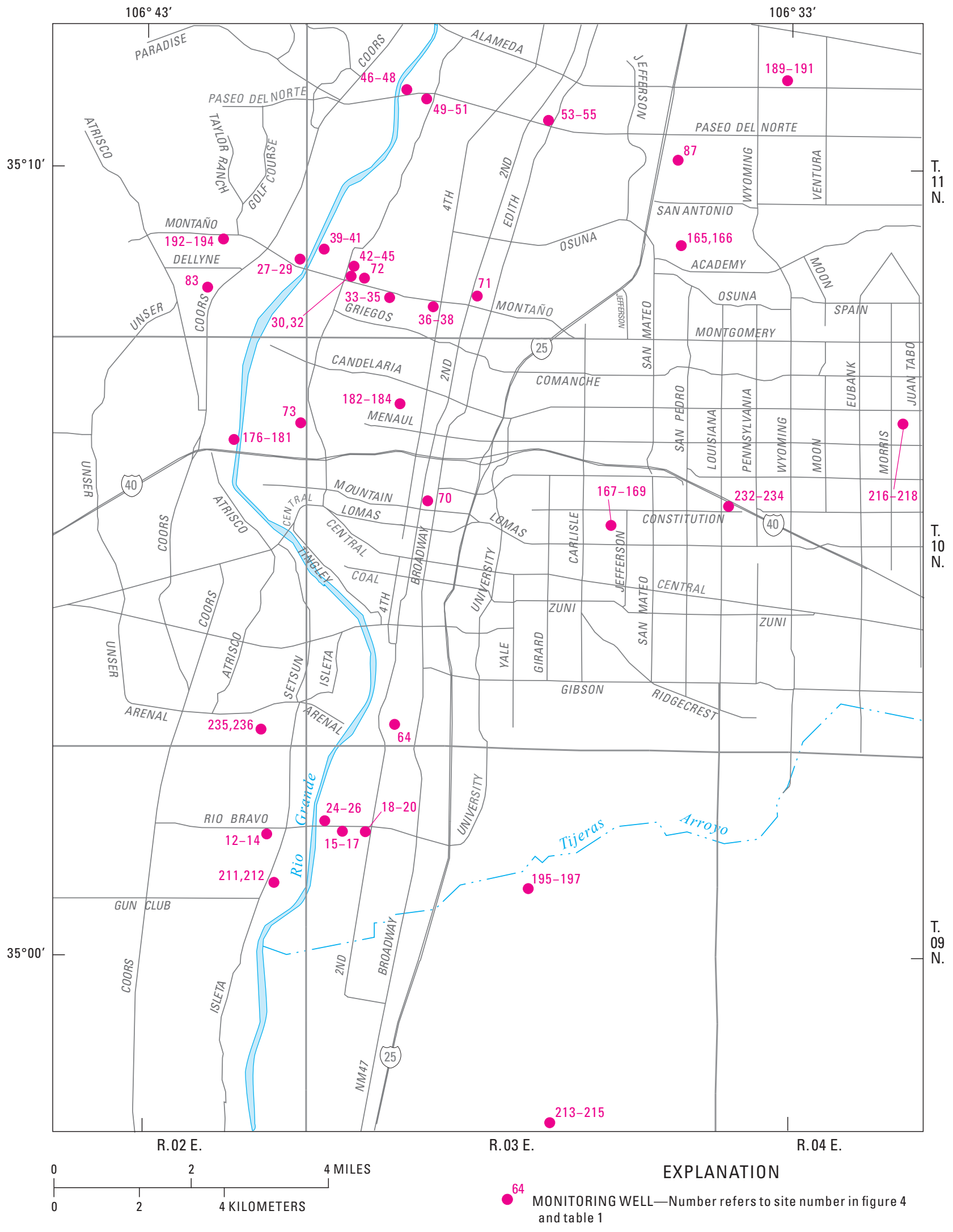

Figure 2. Location of selected monitoring wells and piezometers within the Albuquerque metropolitan area. 


\section{Well-Numbering System}

The system of numbering wells and piezometers in New Mexico is based on the common subdivision of public lands into sections (fig. 3). The well number, in addition to designating the well, locates the position to the nearest 10 -acre tract in the land network. This number (referred to as "local identifier" in table 1) is divided into four segments. The first segment denotes the township north or south of the New Mexico base line, the second denotes the range east or west of the New Mexico primary meridian, and the third denotes the section. The fourth segment of the number, which consists of three digits, denotes the 160-, 40-, and 10-acre tracts in which the well is located. The section is divided into four quarters-numbered 1, 2, 3, and 4-for the northwest, northeast, southwest, and southeast quarters, respectively. The first digit of the fourth segment gives the quarter section, which is a tract of 160 acres. The quarter section is divided into four 40 -acre tracts numbered in the same manner, and the second digit denotes the 40 -acre tract. Finally, the 40 -acre tract is divided into four 10-acre tracts, and the third digit denotes the 10-acre tract. The fourth segment of the well number can further denote subdivisions of the 10-acre tract by including more than three digits. Each additional digit further subdivides the tract by quarters in the same manner as shown in figure 3. Letters A, B, C, and so on are added to the last segment of the well number to designate the second, third, fourth, and succeeding wells in the same tract. For example, well 09N.03E.07.131A is the first subsequent well in the NW $1 / 4$ of the SW $1 / 4$ of the NW $1 / 4$ of section 7, T. 09 N., R. 03 E. (fig. 3).

\section{Methods}

Electric and steel tapes are used to collect water-level measurements at all 124 wells and piezometers. Pressure transducers and data loggers are used to collect hourly water-level data at sites 42-45 (beginning in November 2005), 64, 66, 165-184, 189-227, and 232-236. Sites 2, 4, 8-10, 12-20, 24-30, 32-41, 46-51, 53-55, 67-73, 76, 81, 83, 86, and 87 are measured semiannually. Sites 230 and 231 are measured quarterly.

\section{Well and Piezometer Data and Hydrographs}

Data for the 124 wells and piezometers in the network are listed in table 1. Data include USGS site number and identifier, figure number, local identifier, other identifier (if applicable),

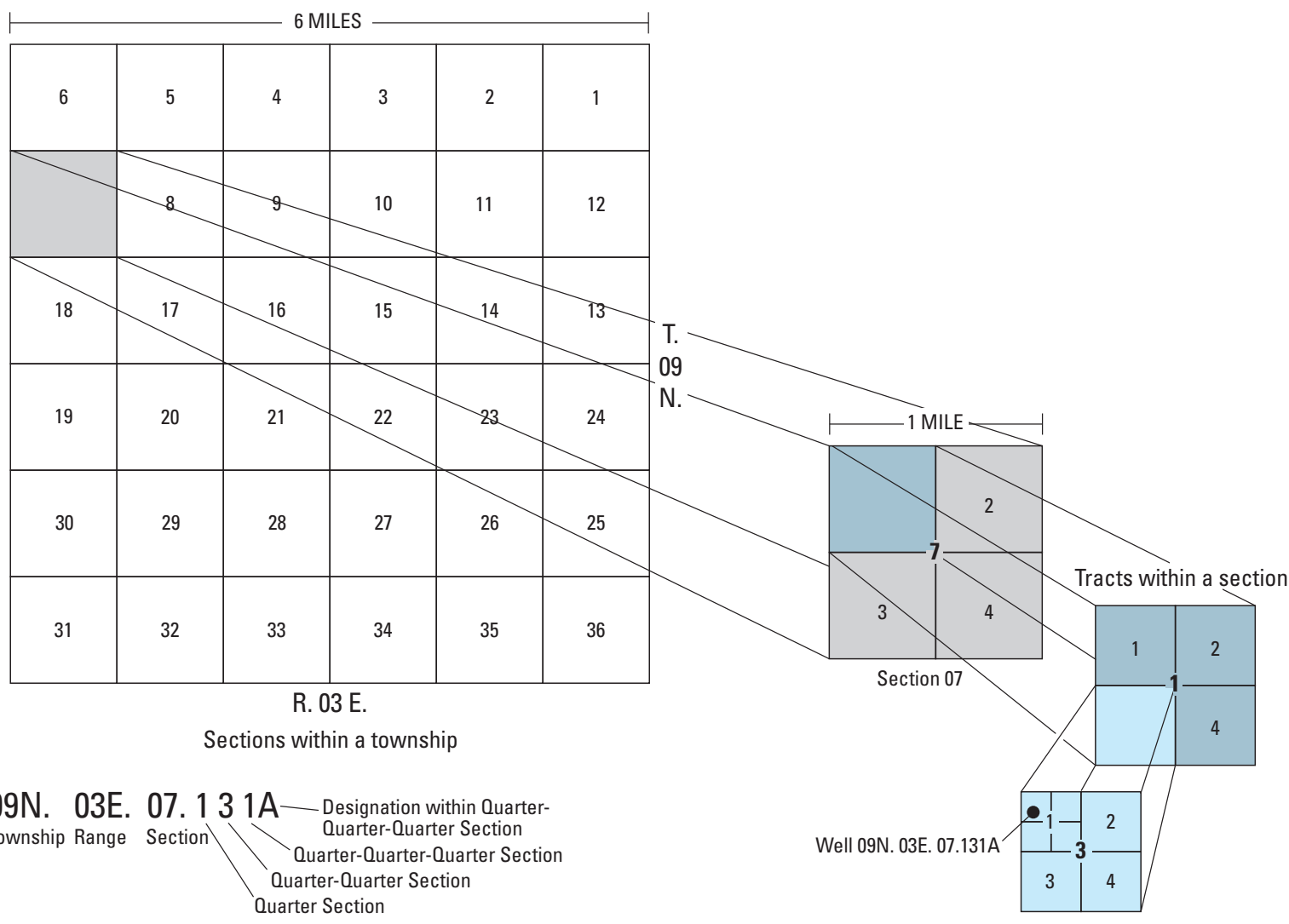

Figure 3. System for numbering wells and piezometers in New Mexico. 
well depth, and screened interval. Hydrographs presenting water-level data collected by the USGS are shown in figure 4. The data presented in the hydrographs include depth to water in feet below land surface and hydraulic head, expressed as altitude in feet above the National Geodetic Vertical Datum of 1929 (NGVD 29). Data in hydrographs from wells that have continuous recorders are shown by solid lines that represent continuous data. In hydrographs that present data from periodically measured wells, dashed lines connect symbols ('+') that represent periodic measurements. In hydrographs showing periodically measured piezometers that are nested (more than one trace per graph), the symbols were removed to make the hydrograph easier to read.

Water-level measurements collected by USGS personnel are presented in 14 previous USGS Open-File Reports (Kues, 1987; Rankin, 1994, 1996, 1998, 1999, 2000; DeWees, 2001, 2002, 2003, 2006; Beman, 2007, 2008, 2009; Beman and Torres, 2010).

\section{References Cited}

Bartolino, J.R., and Cole, J.C., 2002, Ground-water resources of the Middle Rio Grande Basin, New Mexico: U.S. Geological Survey Circular 1222, 132 p. (Also available at http://pubs.usgs.gov/circ/2002/circ1222/.)

Beman, J.E., 2007, Water-level data for the Albuquerque Basin and adjacent areas, central New Mexico, period of record through September 30, 2006: U.S. Geological Survey Open-File Report 2007-1273, 34 p. (Also available at http://pubs.usgs.gov/of/2007/1273/.)

Beman, J.E., 2008, Water-level data for the Albuquerque Basin and adjacent areas, central New Mexico, period of record through September 30, 2007: U.S. Geological Survey Open-File Report 2008-1255, 32 p. (Also available at http://pubs.usgs.gov/of/2008/1255/.)

Beman, J.E., 2009, Water-level data for the Albuquerque Basin and adjacent areas, central New Mexico, period of record through September 30, 2008: U.S. Geological Survey Open-File Report 2009-1125, 37 p. (Also available at http://pubs.usgs.gov/of/2009/1125/.)

Beman, J.E., and Torres L.T., 2010, Water-level data for the Albuquerque Basin and adjacent areas, central New Mexico, period of record through September 30, 2009: U.S. Geological Survey Open-File Report 2010-1228, 31 p. (Also available at http://pubs.usgs.gov/of/2010/1228/.)

DeWees, R.K., 2001, Water-level data for the Albuquerque Basin and adjacent areas, central New Mexico, period of record through 2000: U.S. Geological Survey Open-File Report 2001-184, 62 p.
DeWees, R.K., 2002, Water-level data for the Albuquerque Basin and adjacent areas, central New Mexico, period of record through 2001: U.S. Geological Survey Open-File Report 2002-312, $41 \mathrm{p}$.

DeWees, R.K., 2003, Water-level data for the Albuquerque Basin and adjacent areas, central New Mexico, period of record through 2002: U.S. Geological Survey Open-File Report 2003-321, $41 \mathrm{p}$.

DeWees, R.K., 2006, Water-level data for the Albuquerque Basin and adjacent areas, central New Mexico, period of record through 2004: U.S. Geological Survey Open-File Report 2006-1281, 40 p. (Also available at http://pubs.usgs.gov/of/2006/1281/.)

Kues, G.E., 1987, Ground-water-level data for the AlbuquerqueBelen Basin, New Mexico, through water year 1985: U.S. Geological Survey Open-File Report 87-116, 51 p.

Rankin, D.R., 1994, Water-level data for the Albuquerque Basin, New Mexico, October 1, 1986, through September 30, 1990: U.S. Geological Survey Open-File Report 94-349, 29 p.

Rankin, D.R., 1996, Water-level data for the Albuquerque Basin, New Mexico, period of record through September 30, 1995: U.S. Geological Survey Open-File Report 96-664A, 28 p.

Rankin, D.R., 1998, Water-level data for the Albuquerque Basin, central New Mexico, period of record through 1997: U.S. Geological Survey Open-File Report 98-408, 28 p.

Rankin, D.R., 1999, Water-level data for the Albuquerque Basin and adjacent areas, New Mexico, period of record through 1998: U.S. Geological Survey Open-File Report 99-269, 27 p. (Abstract available at http://nm.water.usgs.gov/ publications/abstracts/ofr99-269.html.)

Rankin, D.R., 2000, Water-level data for the Albuquerque Basin and adjacent areas, central New Mexico, period of record through 1999: U.S. Geological Survey Open-File Report 2000-231, 62 p.

Thorn, C.R., McAda, D.P., and Kernodle, J.M., 1993, Geohydrologic framework and hydrologic conditions in the Albuquerque Basin, central New Mexico: U.S. Geological Survey Water-Resources Investigations Report 93-4149, $106 \mathrm{p}$.

U.S. Census Bureau, 2001, State and county quickfacts: accessed July 15, 2002, at http://quickfacts.census.gov.

U.S. Census Bureau, 2011a, 2010 census centers of population by census tract, updated March 24, 2011: accessed April 25, 2011, at http://www.census.gov/geo/ www/2010census/centerpop2010/tract/tractcenters.html.

U.S. Census Bureau, 2011b, U.S. Census Bureau delivers New Mexico's 2010 census population totals, including first look at race and Hispanic origin data for legislative redistricting: U.S. Census Bureau News, March 15, 2011, accessed May 4, 2011, at http://2010.census.gov/news/ releases/operations/cb11-cn87.html. 


\section{Water-Level Data for Selected Wells and Piezometers in the Albuquerque Basin}



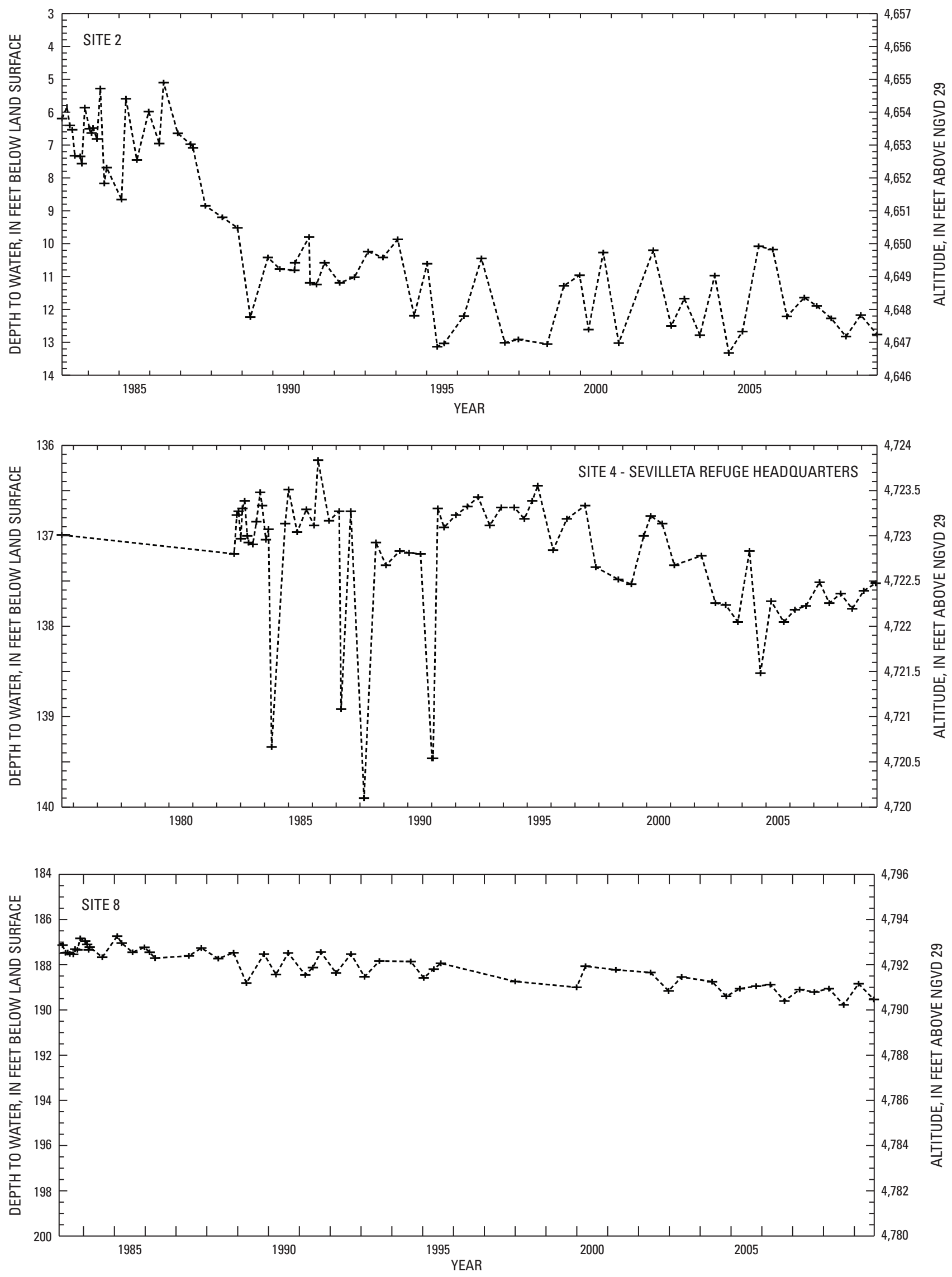

Figure 4. Water-level data for selected wells and piezometers in the Albuquerque Basin. 

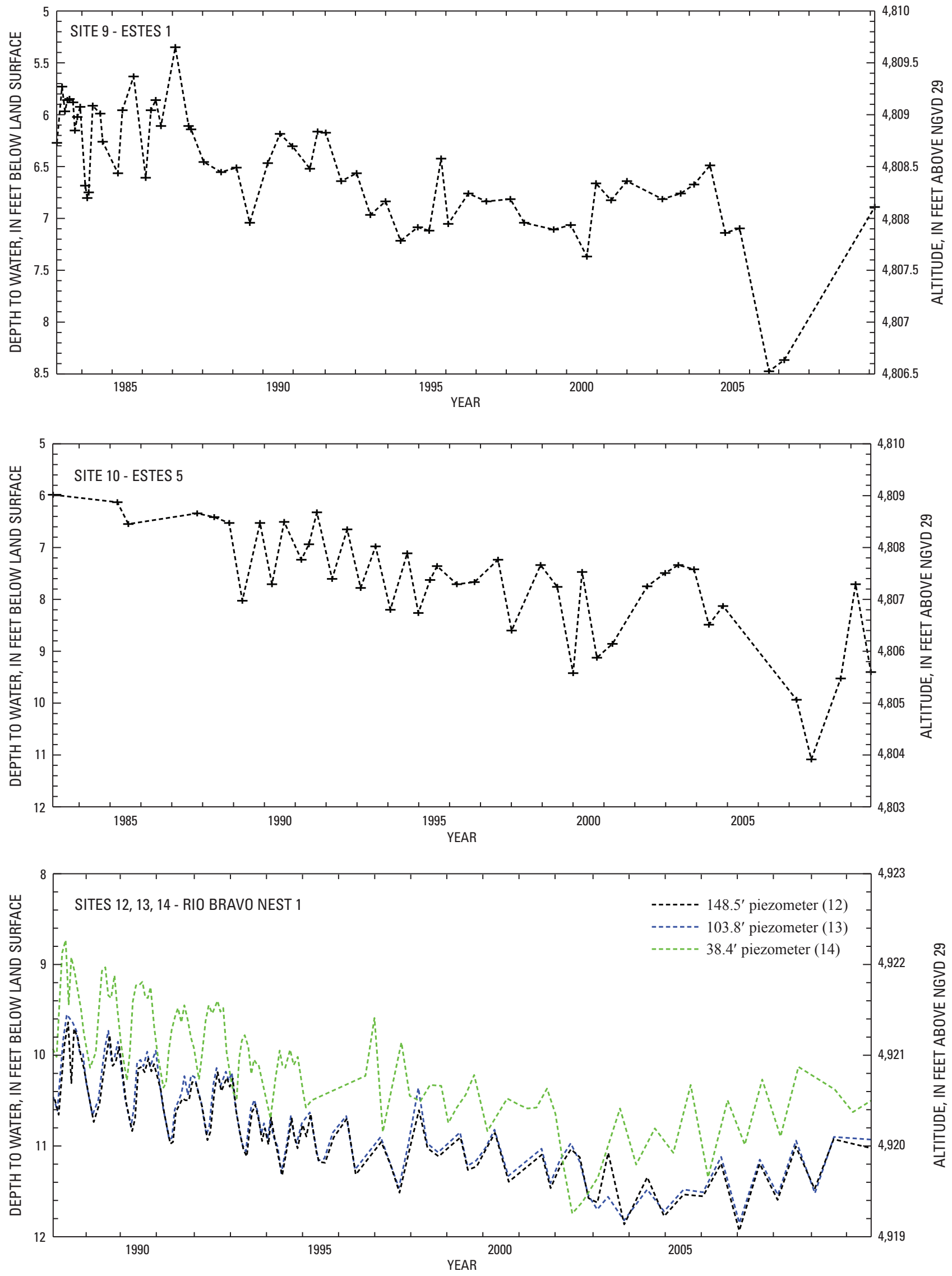

Figure 4. Water-level data for selected wells and piezometers in the Albuquerque Basin.-Continued 

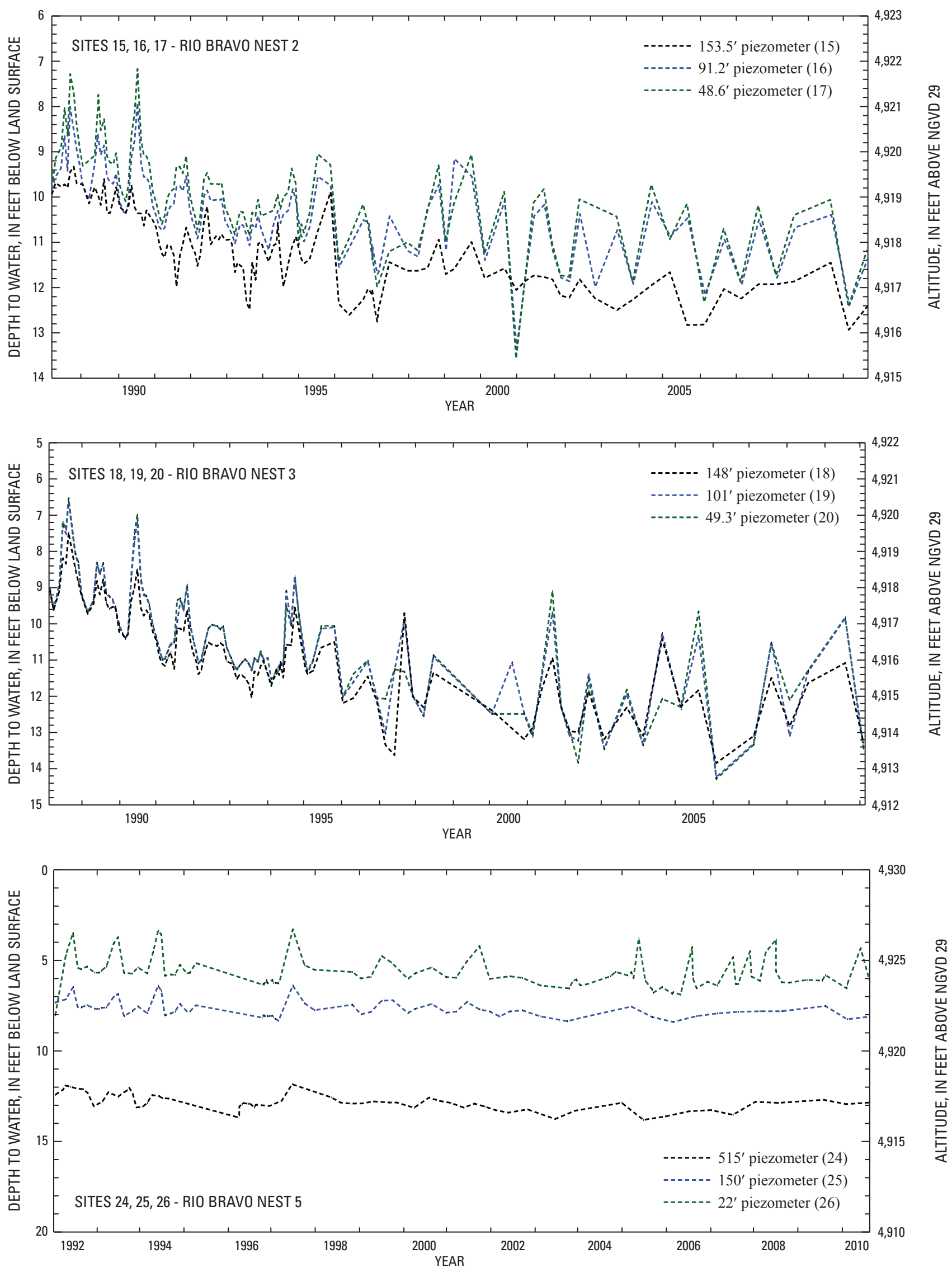

Figure 4. Water-level data for selected wells and piezometers in the Albuquerque Basin.-Continued 


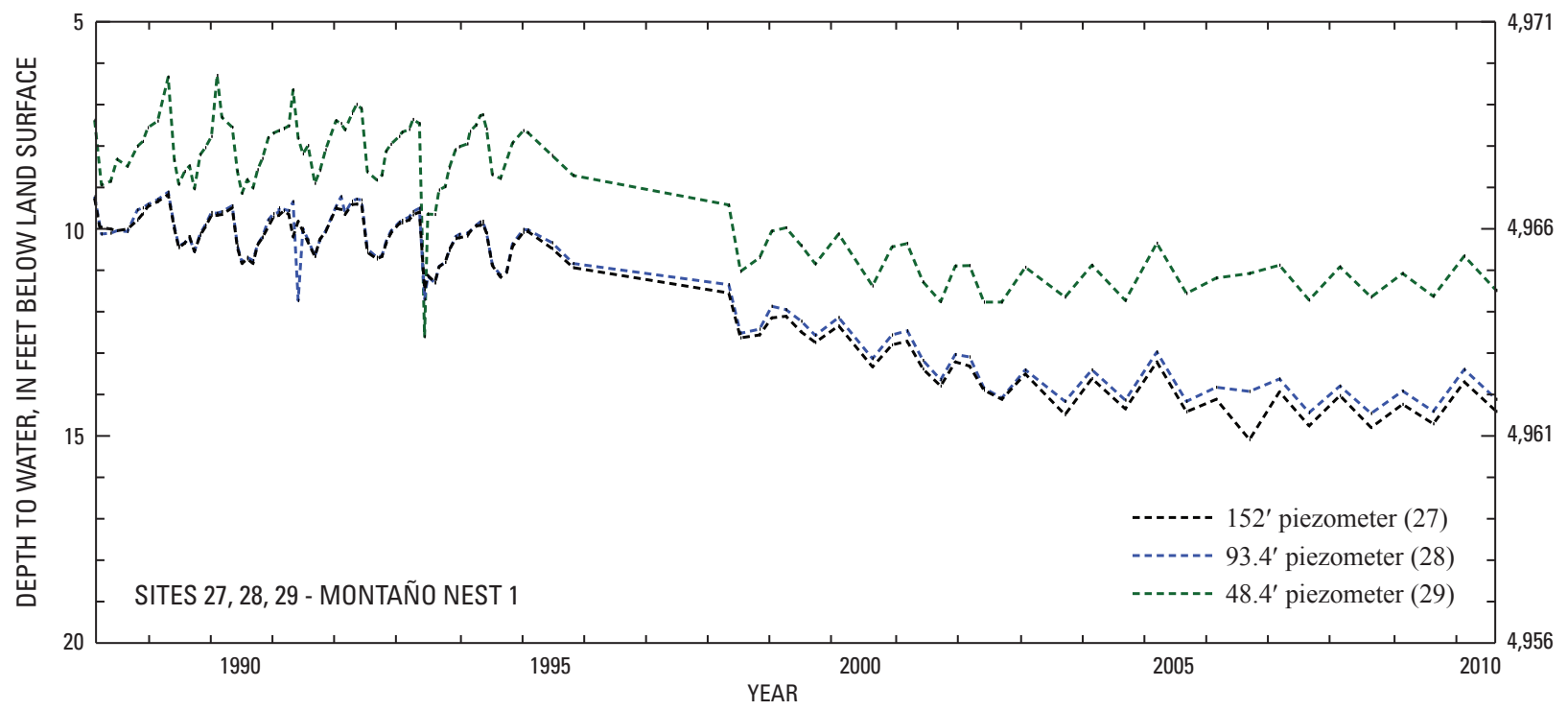

D̃
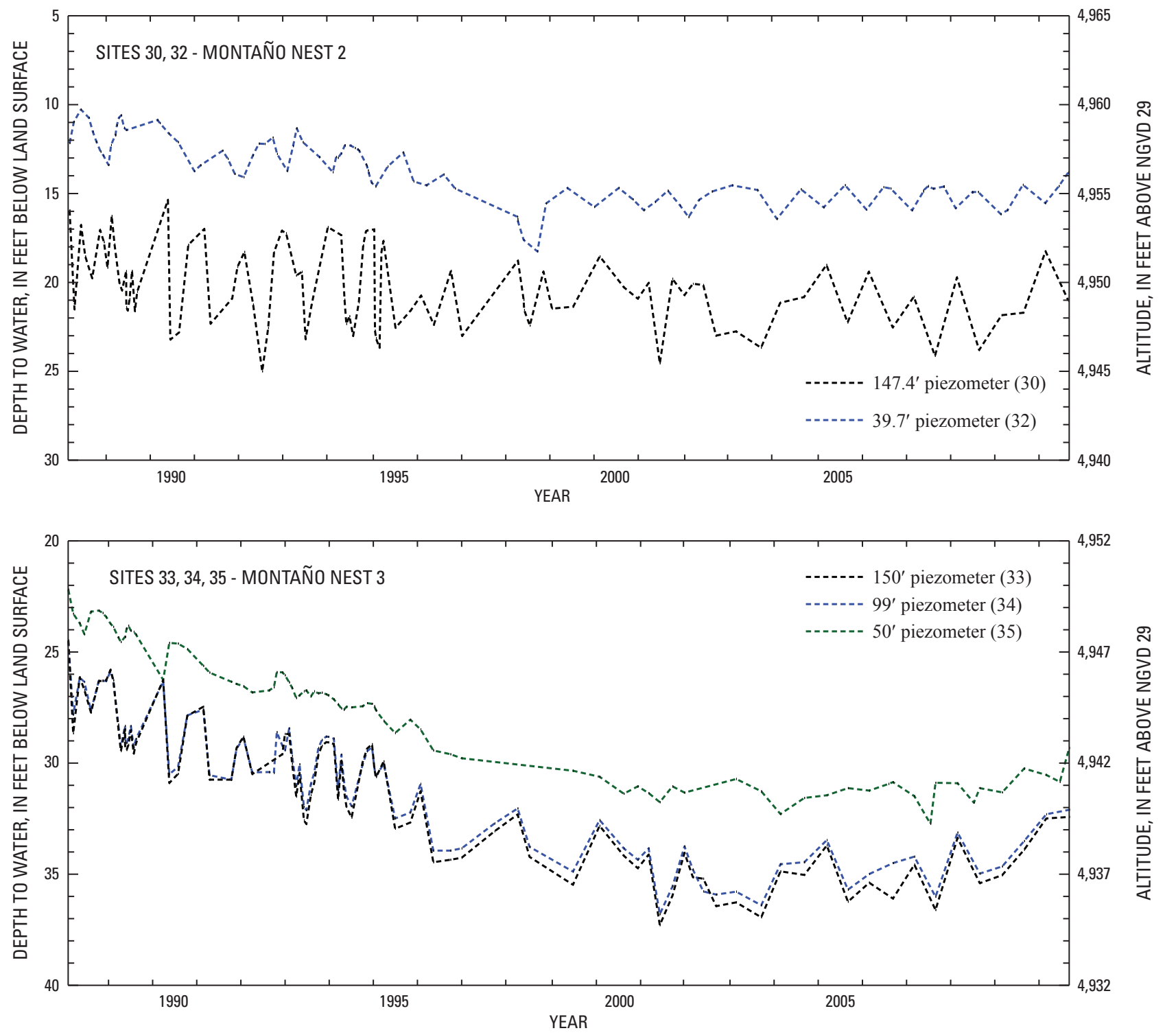

Figure 4. Water-level data for selected wells and piezometers in the Albuquerque Basin.-Continued 

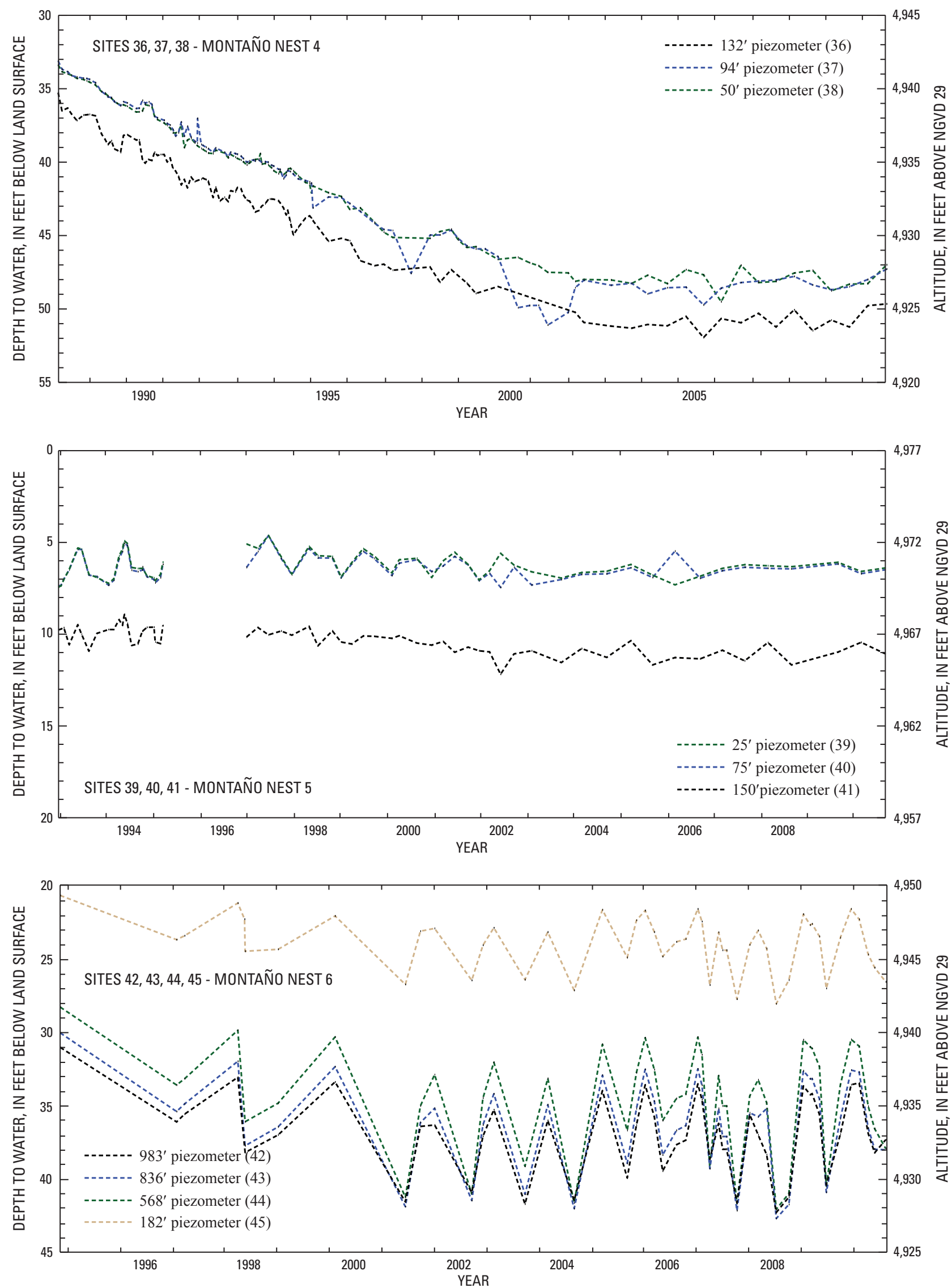

Figure 4. Water-level data for selected wells and piezometers in the Albuquerque Basin.—Continued 

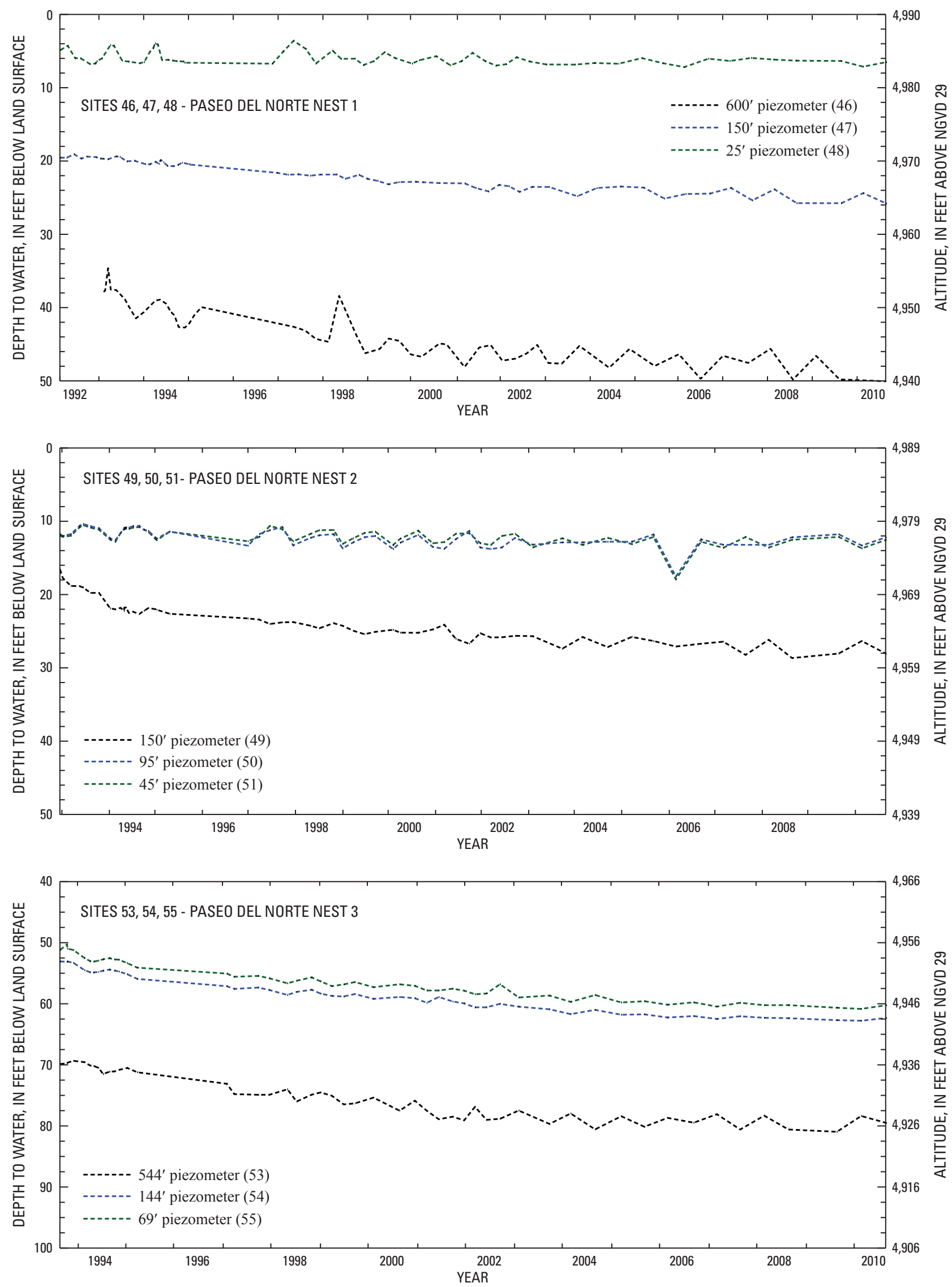

Figure 4. Water-level data for selected wells and piezometers in the Albuquerque Basin.-Continued 

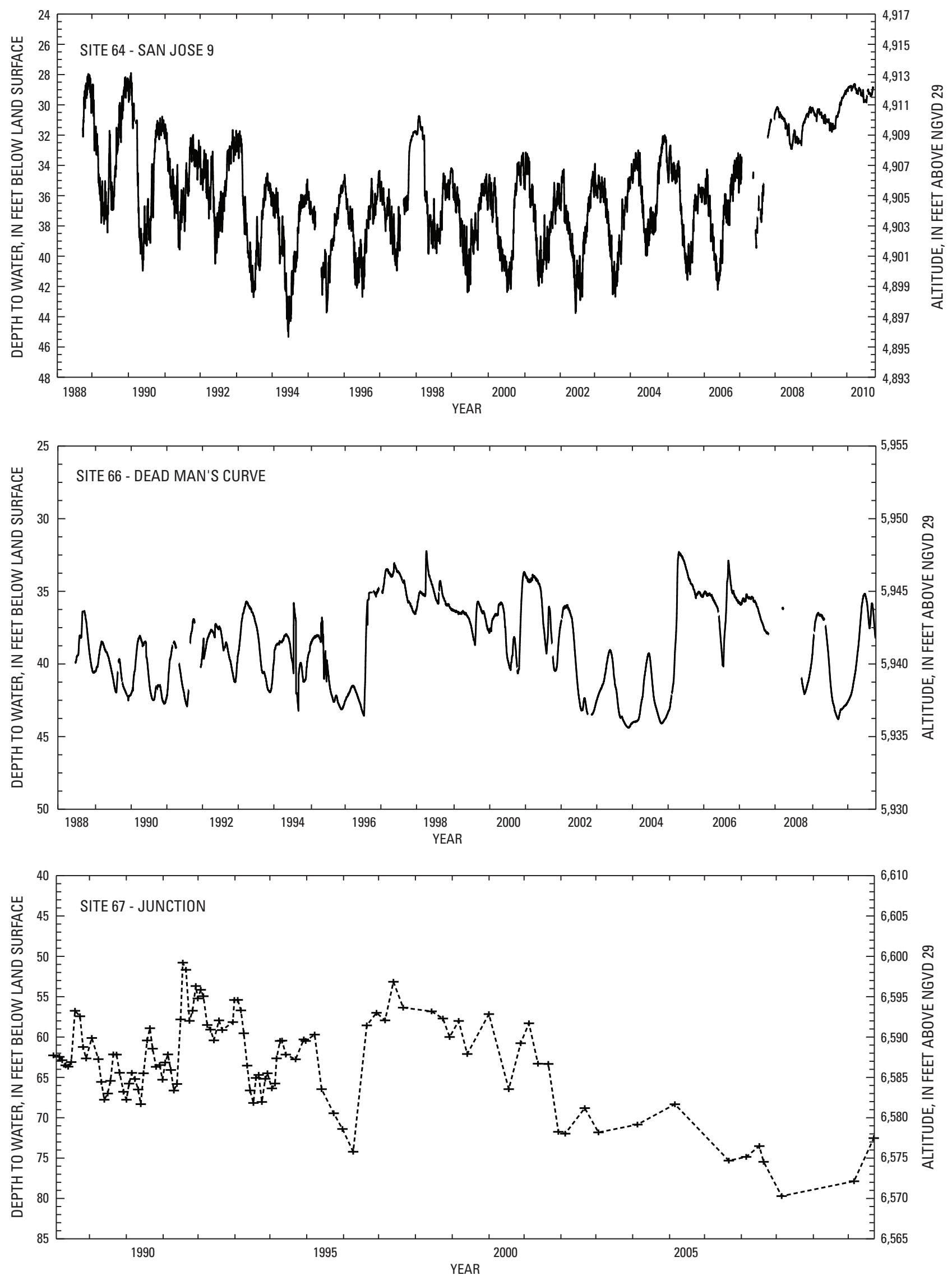

Figure 4. Water-level data for selected wells and piezometers in the Albuquerque Basin.-Continued 

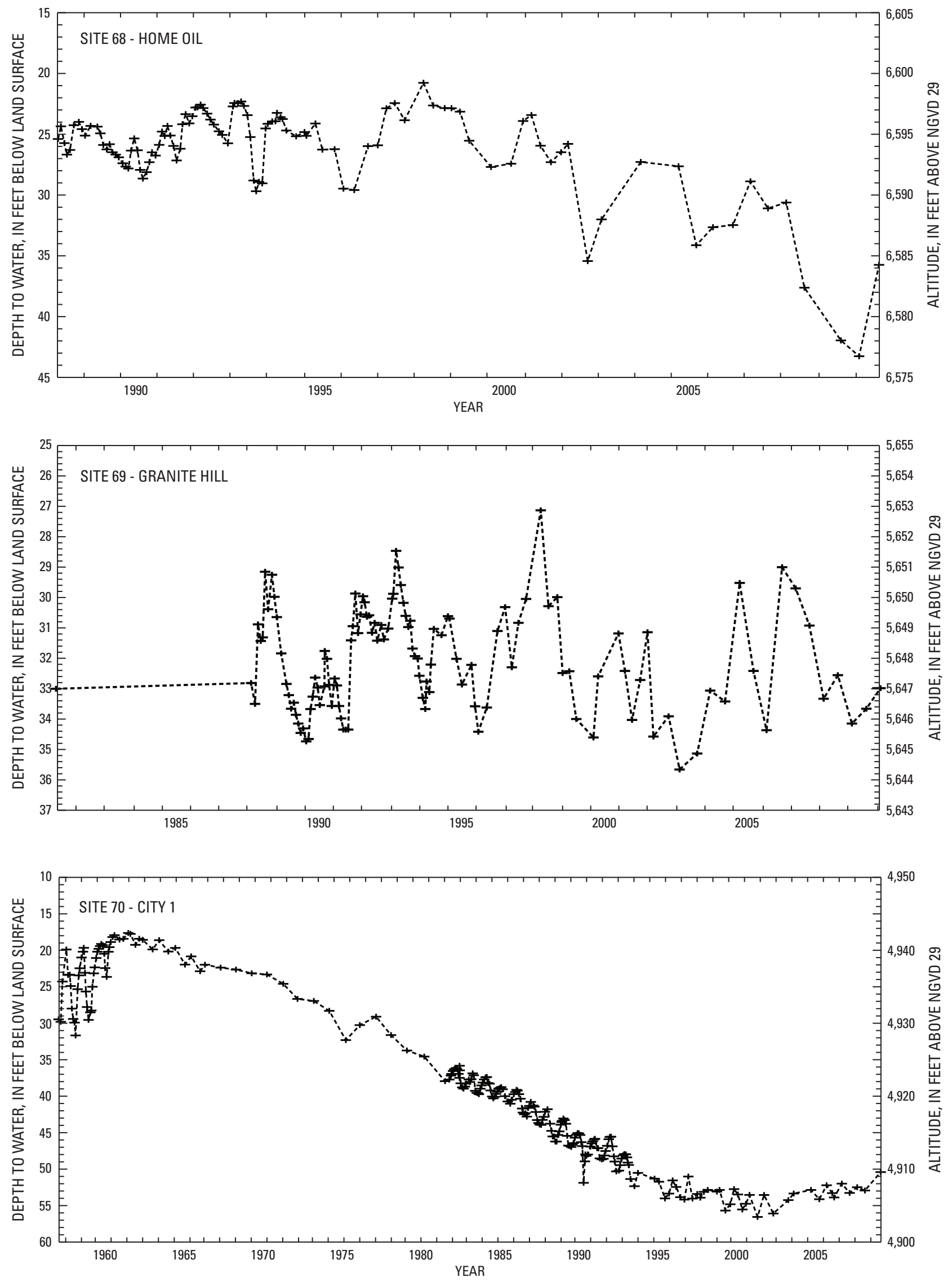

Figure 4. Water-level data for selected wells and piezometers in the Albuquerque Basin.-Continued 

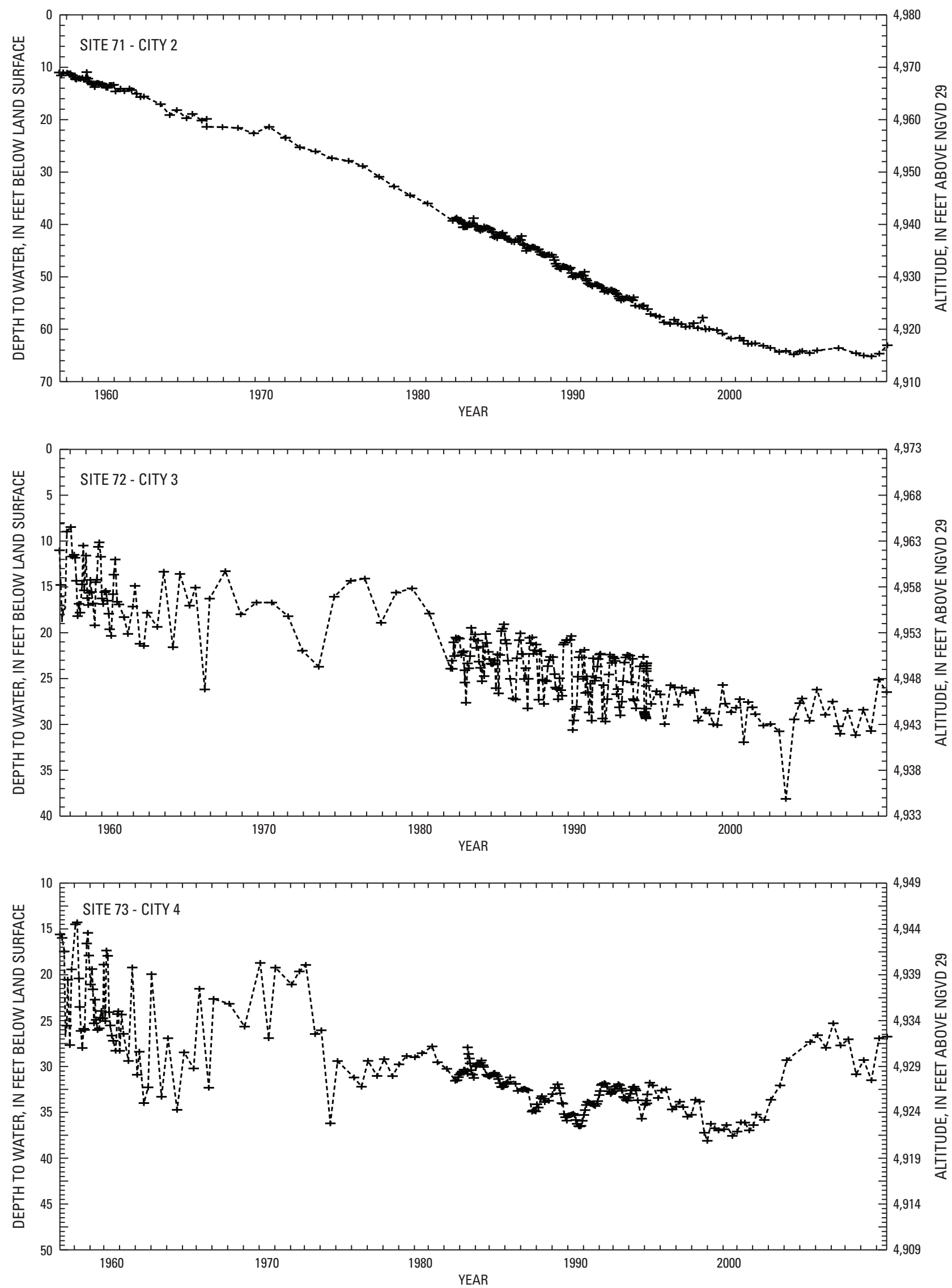

Figure 4. Water-level data for selected wells and piezometers in the Albuquerque Basin.-Continued 

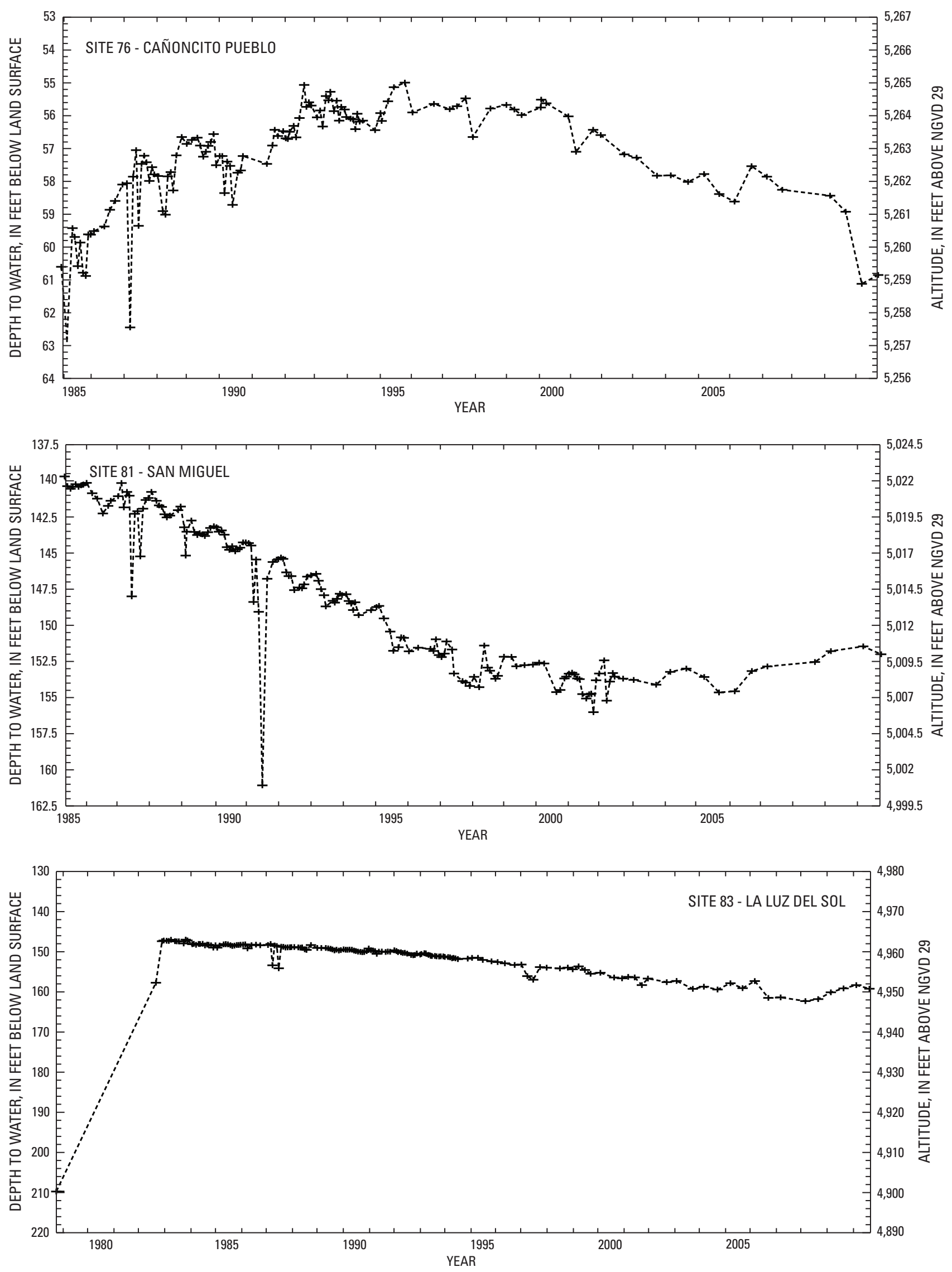

Figure 4. Water-level data for selected wells and piezometers in the Albuquerque Basin.—Continued 

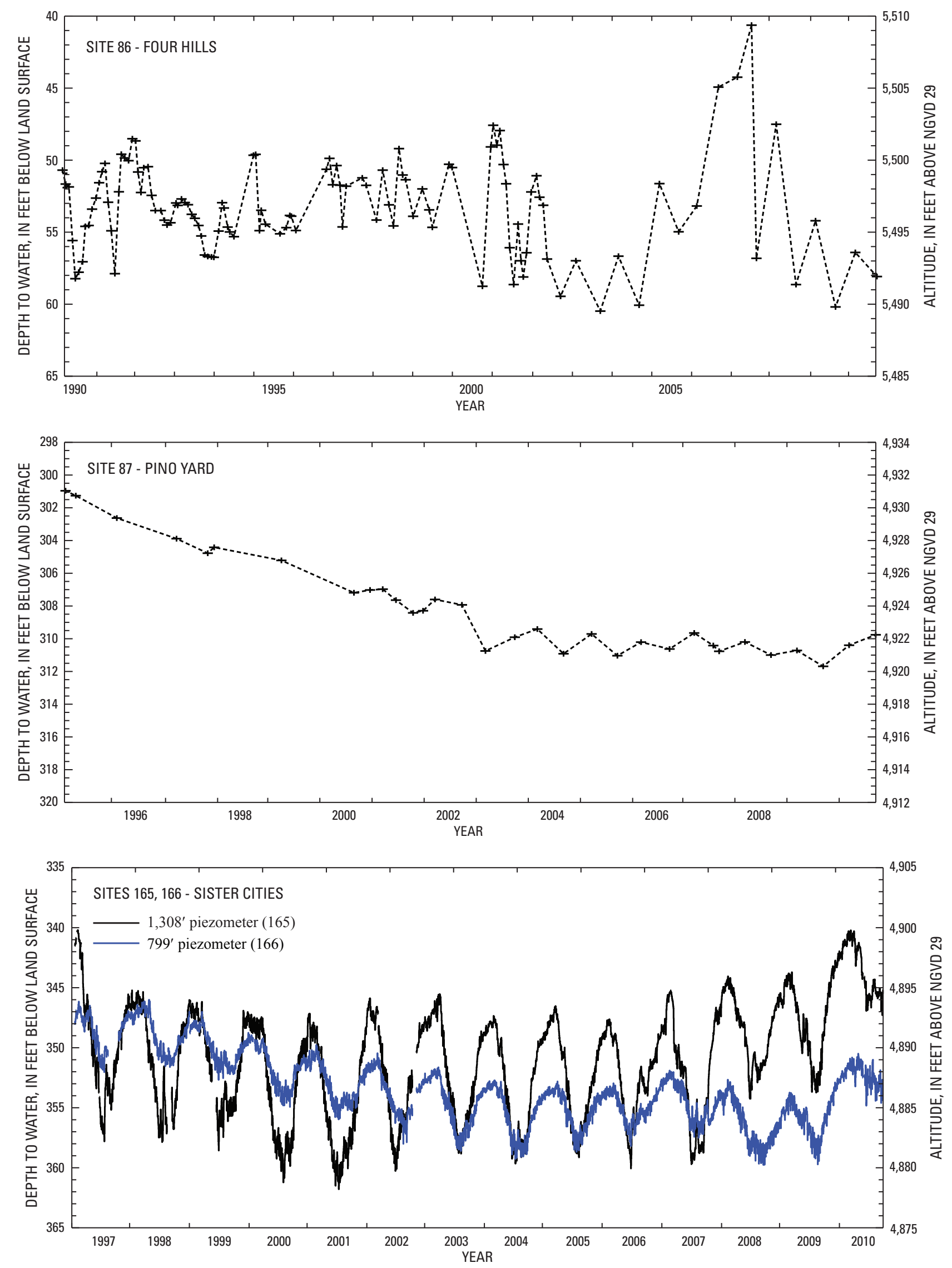

Figure 4. Water-level data for selected wells and piezometers in the Albuquerque Basin.-Continued 

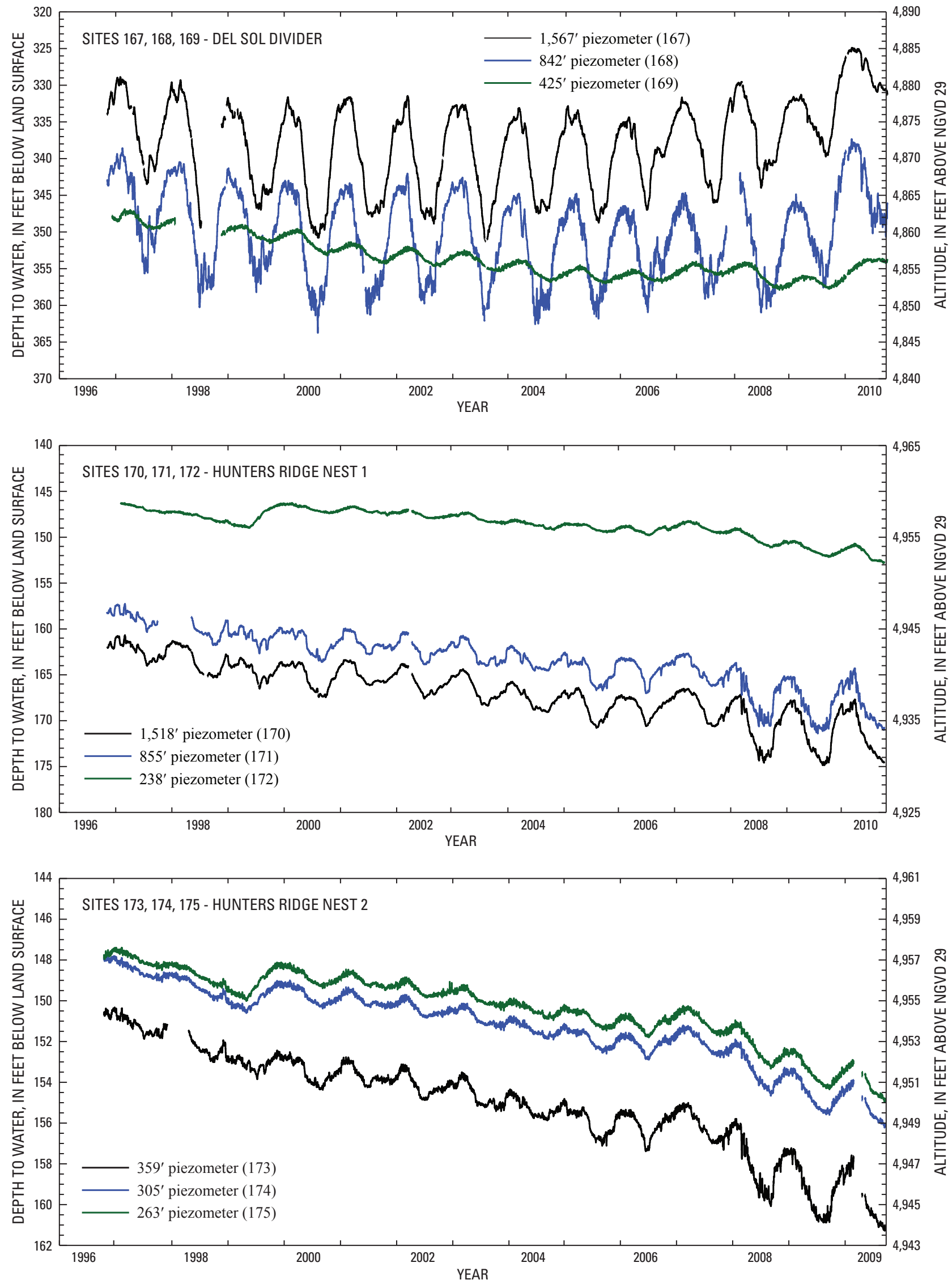

Figure 4. Water-level data for selected wells and piezometers in the Albuquerque Basin.-Continued 

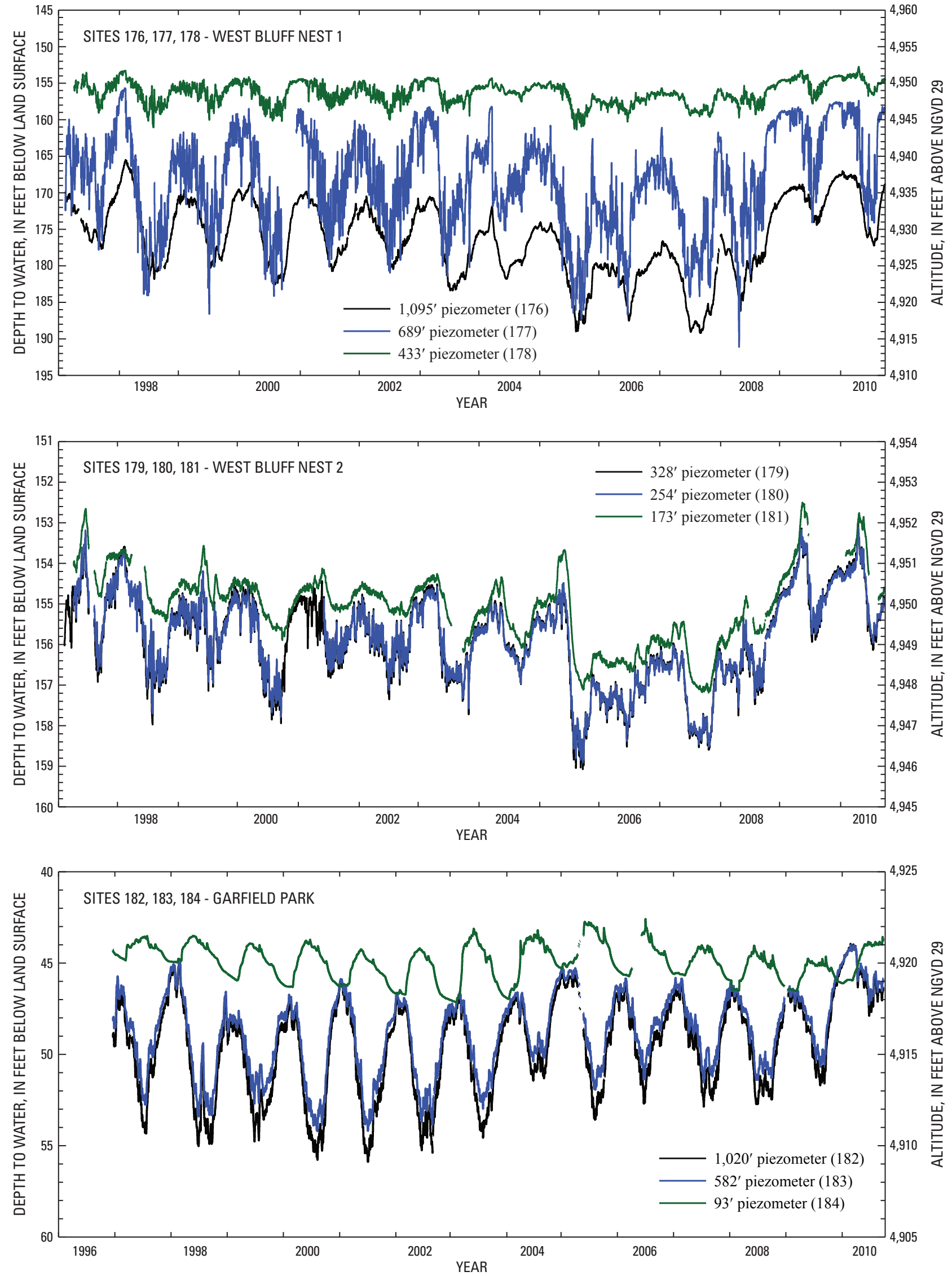

Figure 4. Water-level data for selected wells and piezometers in the Albuquerque Basin.-Continued 

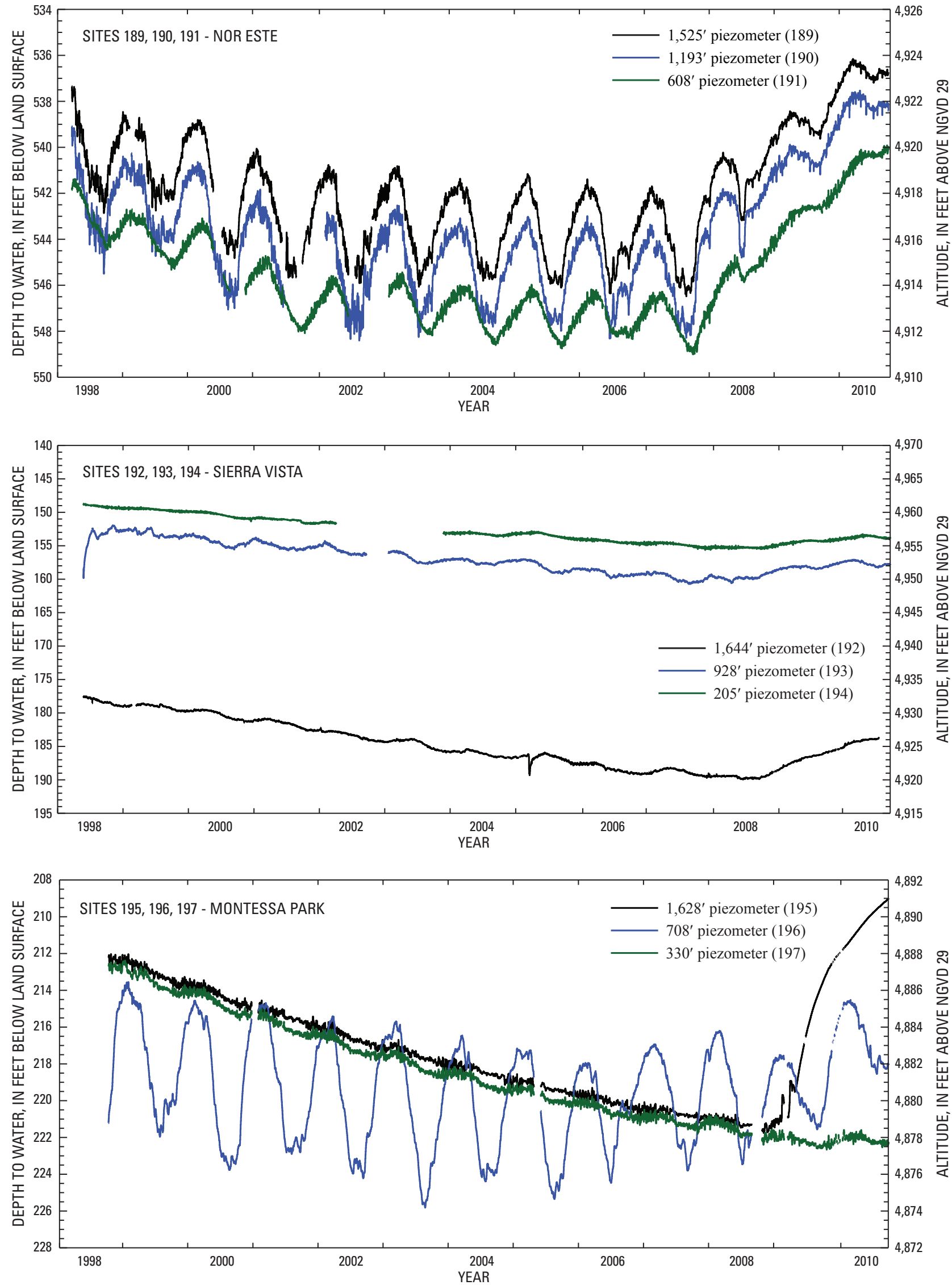

Figure 4. Water-level data for selected wells and piezometers in the Albuquerque Basin.-Continued 

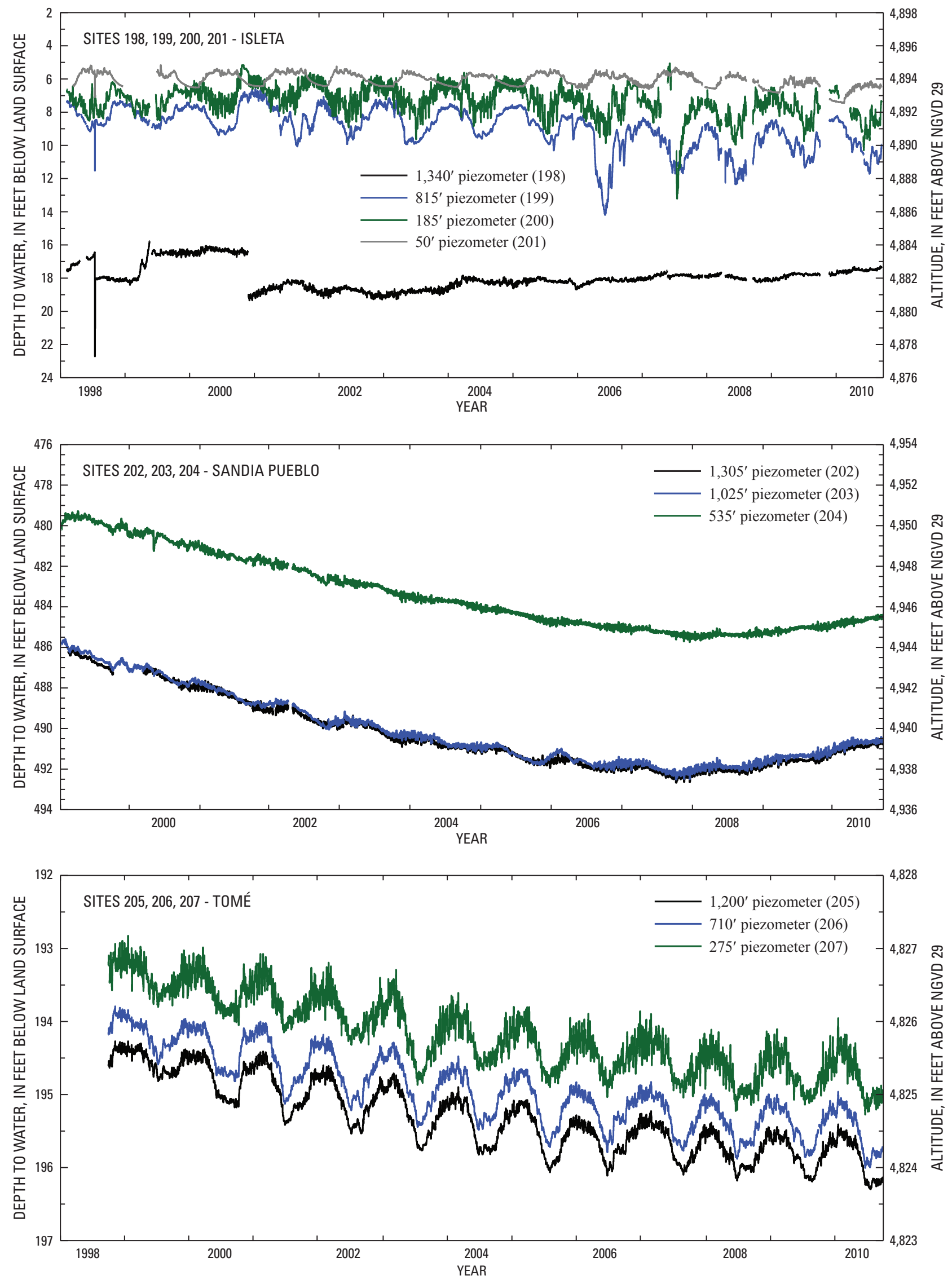

Figure 4. Water-level data for selected wells and piezometers in the Albuquerque Basin.-Continued 

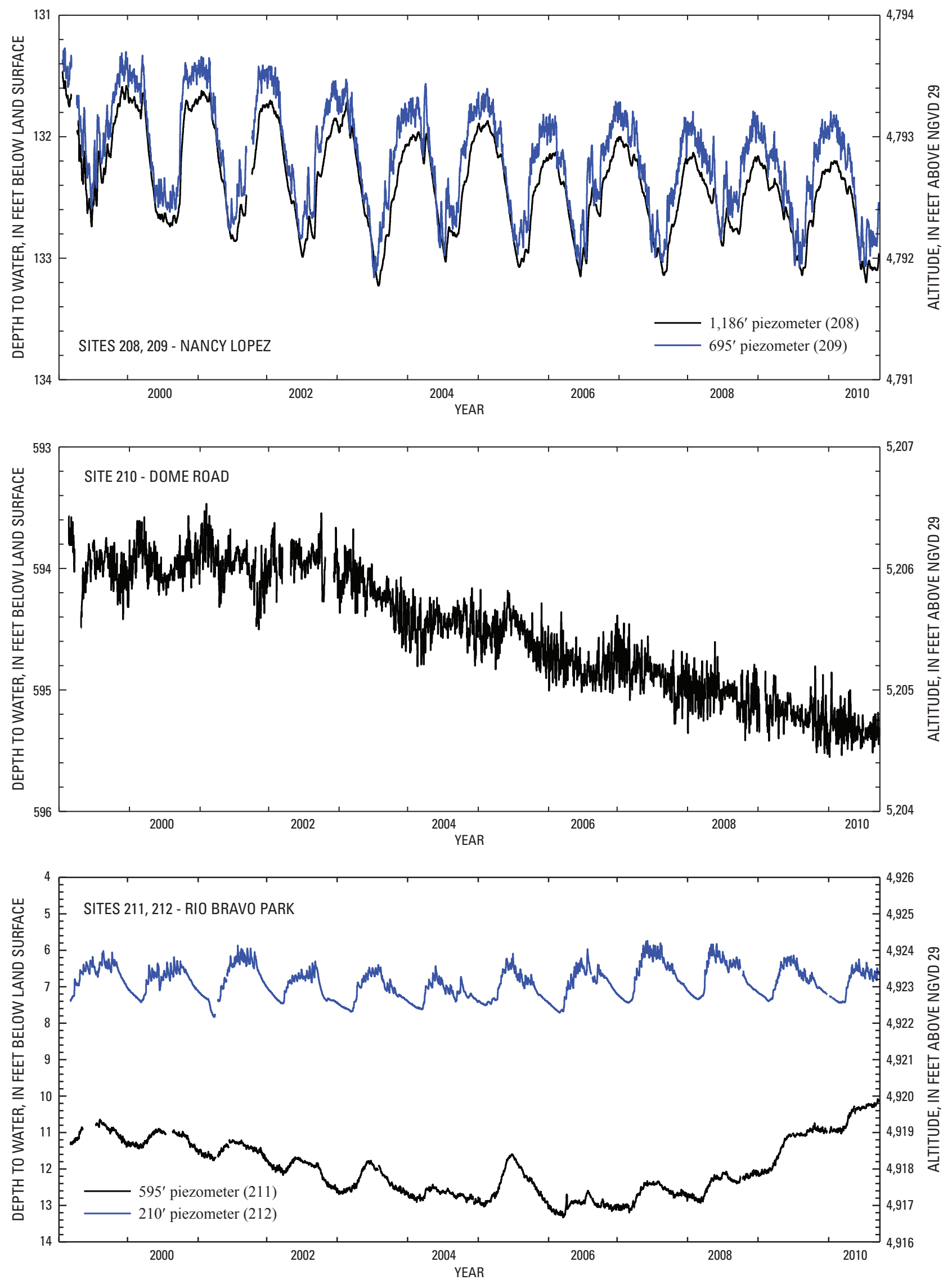

Figure 4. Water-level data for selected wells and piezometers in the Albuquerque Basin.-Continued 

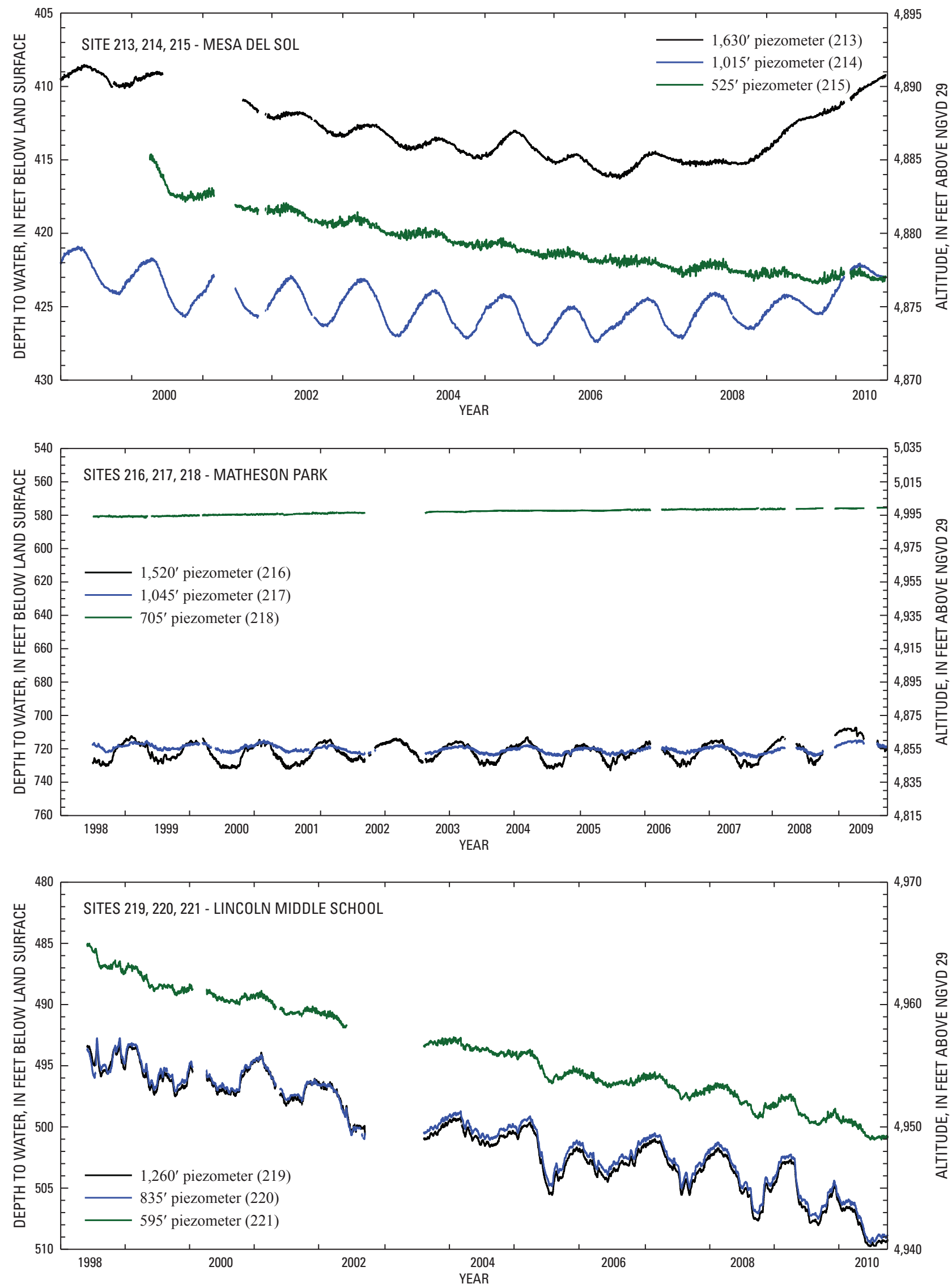

Figure 4. Water-level data for selected wells and piezometers in the Albuquerque Basin.-Continued 

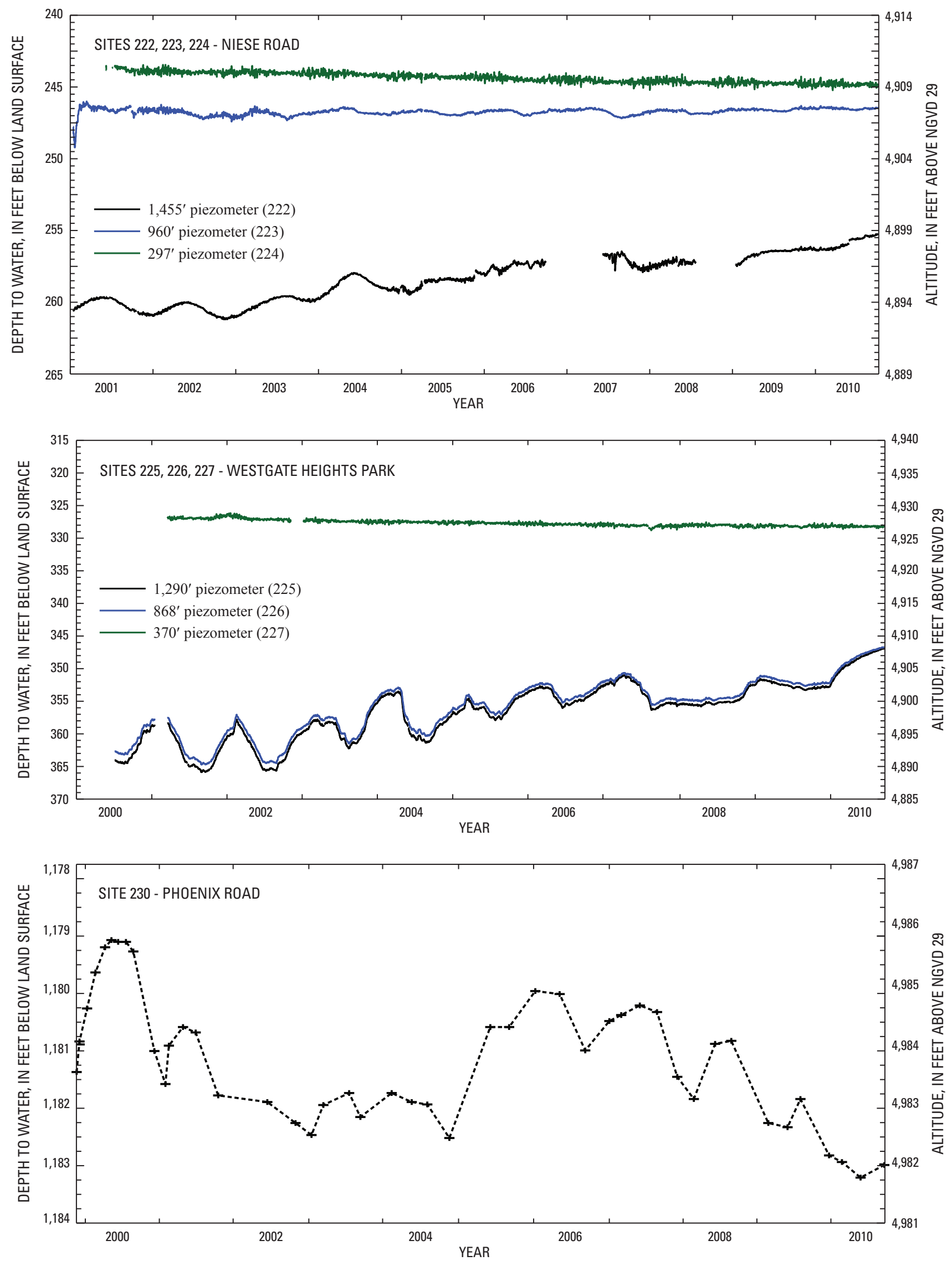

Figure 4. Water-level data for selected wells and piezometers in the Albuquerque Basin.—Continued 

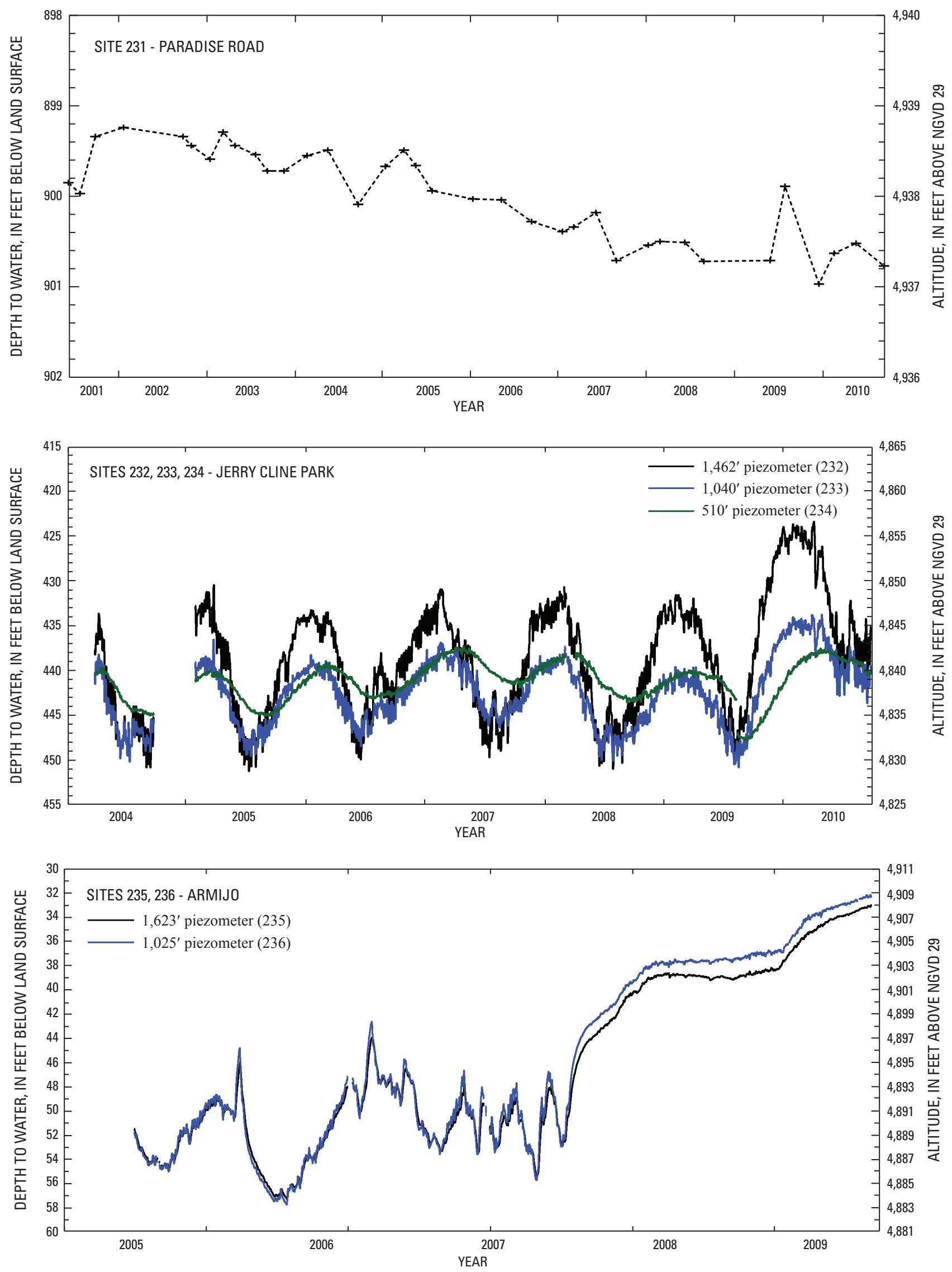

Figure 4. Water-level data for selected wells and piezometers in the Albuquerque Basin.-Continued 
Publishing support provided by:

Lafayette Publishing Service Center

For more information concerning this publication, contact:

Director, New Mexico Water Science Center

U.S. Geological Survey

5338 Montgomery Boulevard NE

Albuquerque, New Mexico 87109-1311

(505) 830-7900

Or visit the New Mexico Water Science Center Web site at: http://nm.water.usgs.gov/ 
